\title{
Ankara Drawings of Eşref Üren and Andre Lhôte’s Influence
}

\author{
Eşref Üren'in Ankara Desenleri ve Andre Lhôte’un Etkisi
}

\author{
Feyza AKDER \\ Post-doc Research Assistant, Koç University Vehbi Koç Ankara Studies Research Center (VEKAM), Ankara, Turkey \\ feakder@ku.edu.tr \\ ORCID ID: 0000-0003-3883-2155
}

DOI: $10.5505 /$ jas.2019.53215

\begin{abstract}
Eşref Üren (1897-1984) is an artist who lived in Ankara in the last 45 years of his life; acknowledged as an imperative personality in Ankara artistic circles. There are at least 100 Ankara landscapes in major art collections in Turkey that belong to him. This article discusses the Ankara drawings of Eşref Üren which are today in İmren Erşen collection, that were drawn after 1939. These drawings reveal fruitful results when analyzed with Turkish drawing history from the literature. Üren has been evaluated mainly as an impressionist painter. Therefore, the French painter André Lhôte’s (1885-1962) influence over Üren's paintings and drawings, especially his works after 1950 has been undervalued. These drawings also signify some findings as to how Ankara's urban texture influenced paintings. The first part of the article covers how Üren's drawing views followed a pattern and matured. In the second part, we will explain the plastic relationship between his drawings and Ankara. The analysis of Eşref Üren's Ankara drawings, in the light of new data from Eşref Üren's unpublished drawing pads and diaries, offers a new point of view to André Lhôte's strong influence over Eşref Üren. What is more, they will point to how Ankara’s urban texture influenced Üren between 1950 and 1980 while he drew these examples.
\end{abstract}

Keywords: Eşref Üren, André Lhôte, Drawing, École Beaux-Arts, Ankara landscapes, Ankara

$\ddot{O} z$

Eşref Üren (1897-1984), yaşamının son 45 yılını Ankara'da geçirmiş; Ankara sanat çevresinde önemli bir kişilik olarak kabul edilmiştir. Türkiye’deki büyük resim koleksiyonlarında 100’ün üzerinde Ankara manzara resmi bulunmaktadır. Bu çalşsma, Eşref Üren’in, İmren Erşen koleksiyonunda bulunan, 1939 yllından sonra çizdiği Ankara desenlerinden örnekleri ele almaktadır. Sözü edilen desenler, literatürden de faydalanlarak, Türk desen tarihinin analizi eşliğinde incelendiğinde verimli sonuçlar ortaya çıkarmaktadırlar. Literatürde ağırlıkla empresyonist bir sanatçı olarak değerlendirildiği için, Fransız ressam André Lhôte’un (1885-1962) Üren’in desenleri ve resimleri üzerindeki etkisi özellikle 1950’li yllardan sonraki çalışmalarında göz ardı edilmiştir. Desenler ayrıca 1950 sonrasında Ankara’nın kentsel dokusunun resim sanatına nasıl aktarıldı̆̆ ile ilgili önemli veriler sunmaktadır. Çalışmanın ilk bölümü Üren’in desen anlayışııın nasıl bir gelişim izleyerek olgunlaştığına ayrılmıştır. İkinci bölümde Üren’in Ankara kenti ile resim ve desen yaparak kurduğu ilişki açıklanmaktadır. Üren'in yayımlanmamış desen defterleri ve günlüklerinden elde edilen yeni veriler ile yapacağımız analiz ışı̆̆ında Eşref Üren’in Ankara desenlerinin, Türk desen tarihinde André Lhôte’un güçlü etkisinin göstergeleri olduğunu ve Ankara’nın özellikle 1950 ve 1980 yılları arasında bu etkiler ışığında resim sanatına nasıl yansıdığına dair bir bakış sunacaktır.

Anahtar sözcükler: Eşref Üren, André Lhôte, Desen, École Beaux-Arts, Ankara manzaraları, Ankara 


\section{Introduction}

The most elaborate collection of Turkish drawings is the collection of Mimar Sinan University İstanbul Painting and Sculpture Museum's. There are 97 drawing pads and 2745 sheets that belong to 51 artists. This inventory revals the main data for Turkish drawing history. The Museum collection reveals several styles, consecutively relating to the views of late $19^{\text {th }}$ century École Beaux-Arts of Paris, post-cubist and constructive styles of the French painter André Lhôte and the German painter Hans Hofmann (1880-1966), abstractions of the nudes and portraits, and a new expressionist view of figures during the 1960s (Akder, 2015, p. 1). But the museum collection does not have any drawings of Eşref Üren. The literature of Turkish art history often emphasizes Lhôte as the beginning of post-cubic and constructivist tendencies; however, the contribution of Eşref Üren's Ankara drawings to the literature is the prolonged influence of André Lhôte's theories. In this article, I purpose to insert Eşref Üren's Ankara drawings which reflect the mentioned influence, into Turkish drawing history.

This article is introducing 16 unpublished drawings of Eşref Üren (Figure 6, 7, 8, 11, 12, 13, 14, 15, 16, 17, 18, $19,20,21,22,24)$. One of these is drawn in the studio established in Ankara Halkevi for professional artists. ${ }^{1}$ Although this drawing is a nude it reveals a very important era in Ankara's artistic life. I was very privileged to read Üren's diaries from 1938 until 1970, which are not published yet, and the letters and post-cards that he kept. I tried to give reference to them as much as possible. ${ }^{2}$

\section{Sources of Turkish Drawing History}

The art of drawing developed within three branches in the Ottoman Empire during the $19^{\text {th }}$ century: Students who had further art education in England, France, and Germany; the Imperial Art Academy and military schools. Eşref Üren's drawings have at least three intersections with these three branches. Üren was a student at the Imperial Fine Arts Academy. He attended two times to André Lhôte's studio hence was involved in encounters with the European Art. And he connected himself with (in his writings in the 1970s) Hoca Ali Riza's (1858-1930) drawing manuals hence the military schools (Ural, 1997, p. 33; Üren, 1971b, p. 7; Üren, 1971a, p. 6). ${ }^{3}$

The first source of Turkish drawings was talented students who were sent abroad to improve their education, as we mentioned before. ${ }^{4}$ The education these men got is imperative for Turkish art history as they became teachers and headmasters in several institutions which had drawing lessons in their curriculum. Leading examples of these schools are the Imperial School of Naval Engineering (Mühendishâne- $i$ Bahrî Hümâyun) which was established in 1776; the Imperial School of Engineering (Mühendishâne-i Berrî Hümâyun) which was established in 1795, The Imperial Military School (Mekteb-i Erkân-ı Harbiyye-i Şâhâne) which was established in 1834, and The Imperial Fine Arts Academy (Sanâyi-i Nefîse Mektebi Âlîsi) which was established in 1882 (Çolak, 2011, pp. 2, 3; Cezar, 1995, p. 456).

The second source of Turkish drawings was military schools that were mentioned above. The variety of the drawing classes in the military school curriculums was condensed and consistent with the publications in the late $19^{\text {th }}$-century Paris and French drawing terminology (Akder, 2015, p. 58). ${ }^{5}$ The Imperial Military School's students became its masters, Süleyman Seyyid, Osman Nuri Paşa, Hoca Ali Rıza, Halil Paşa, Menazırcı Rıza

1 Halkevleri (People's Houses) were cultural and political centers established to spread the masses with the nationalist, secularist and populist ideas of the Turkish Republic between 1931 and 1951 (Karpat, 1974, p. 69). Ankara Halkevi was established in Ankara, in 1932, as the modern capital's people's house (Anonymous, 1932, p. 5).

2 I should like to thank to İmren Erşen for allowing the images from her collection to be published.

3 Eşref Üren attended all the classes of the Academy and completed the courses successfully. However, Academy regulations of the time did not allow a student over 30 years old to get a diploma. As a result Eşref Üren was never graduated from the Academy (Erşen, 2013, p. 16).

4 Ferik İbrahim Paşa (1815-1891), Ferik Tevfik Paşa (1845-1936), Hüsnü Yusuf Bey (1817-1861) were followed by celebrated Osman Hamdi Bey (1842-1910), Şeker Ahmet Paşa (1841-1907), Halil Paşa (1857-1839) and Süleyman Seyyid (1842-1913) were amongst these students (Artun, 2007, p. 34).

5 The curriculum of The Imperial Military School had changed several times during the 19th-century. These were botanical drawings (nebatat resimleri), geometrical drawings (hendese-i resmiyye, dessin géométrique), machine drawings (fenni makine ve eşkali- dessin de machine), (istihkamat-1 cesime eşkali), (nazariyat), (fenn-i kutuğ), (resmi hatti- dessin au trait), (dessin linaire), (harita tersimi), (karakalem resim), (boyama-dessin coloré), (menazır-perspective), (gölge-dessin ombre), (enva-i resim), (çini ile resim), (resim kopyası), (modelden resim), (tarama-hachures), (müsvedde), (mefasil bahsi), (fotoğrafçılık), (elbise tarihi) (Çolak, 2010, pp. 224-225; Akder, 2015, pp. 58-72). 
are the most famous of these masters. ${ }^{6}$ Although The Imperial Military School's drawing could be categorized as a drawing school in its own right, it was not appreciated during the Republican era. The Military School's curriculum did not consist of human figure studies. This was the main criticism directed to the Military School's drawing curriculum.

The third source was the Imperial Fine Arts Academy. The State Fine Arts Academy succeeded the Imperial Fine Arts Academy with minimal changes after the proclamation of the Republic (1923). Although this institution was an Imperial establishment, the new government supported the school. The name of the school was one of the things that changed. Drawing classes and practices of this school proved imperative for Turkish drawings history (Güler, 2014, pp. 102-103).

\section{Encounters of the Second Constitutional Era Students in France: Eşref Üren's Masters in the Imperial Art Academy}

The Ottoman Empire's cultural encounters with Europe is a very efficient context for almost every branch of the humanities, as it is for art history. Eşref Üren, his teachers and the Academy were affected by these cultural encounters. Üren's masters in the Imperial Art Academy were students during the Second Constitutional Era (1908-1920). They fall into all three categories that shaped the Turkish drawing history. Üren attended İbrahim Çallı's (1882-1960) studio in the Academy. Çallı was sent to Europe after completing the classes at the Imperial Art Academy (Güler, 2014, p. 17). And Üren's first drawing teacher Hikmet Onat (1882-1977) graduated first from the military academy, attended the Imperial Art Academy, and then he was sent abroad too (Çolak, 2010, pp. 116-117).

Since its establishment in 1883, the Imperial Fine Arts Academy had been applying a drawing curriculum which was similar to École des Beaux-Arts of Paris. First regulations of the academy included drawing lessons, and the first drawing master of the academy was a Polish painter, Joseph Warnia Zarzecki (1850-?). The scope of the lessons was mostly drawing the plaster molds of flowers and other ornaments in the beginning (Cezar, 1995, pp. 465, 467). The drawing classes of the École did not include drawing from molds, but the prep drawing schools and the studios in France did. Perfecting this skill was an elementary step for becoming an adequate candidate for the École auditions (Boime, 1986, pp. 2328). ${ }^{7}$ Since there were few drawing studios in İstanbul, at the time, these steps became a compulsory part of the courses in the Academy. ${ }^{8}$ The uncharted territory was organizing a curriculum in an official education institute for drawing from a human model and a naked one. ${ }^{9}$

6 Joseph Schranz (1803-1853) became the drawing master of The Imperial Military School in 1837. Schranz, unfortunately, a little known figure today, was often mentioned in the Ottoman records as Mösyö Şırans. Although Schranz is often emphasized in Turkish art history literature more, it is possible that Monsieur Gués (Mösyö Gués, Mösyö Kez, Meusieur Gués) who became the drawing and watercolor master in The Imperial Military School was more effective and influential. He was the master of Süleyman Seyyid (1842-1913), Osman Nuri Paşa (18391906), and Hoca Ali Riza (1858-1939). Monsieur Gués was born in Istanbul and continued as a teacher until his death. Gués spent 40 years of his life in Istanbul teaching drawing. He was educated in Italy. This amount of information is also very scarce; however, more than what we know about Joseph Schranz. And above all, in case of drawing it implies a very significant point. As an Italian scholar, he most probably thought a different way of drawing than French dessin au trait (Cezar, 1995, p. 390; Mahir, 1988, p. 112).

7 Eşref Üren mentions some events in Academy Lhôte that signifies Lhôte took notice of the École. On 5th December 1938, Üren wrote that, in the afternoon Lhôte was going to show them the paintings, drawings, engravings, and sculptures of the old students of École des Beaux-Arts Paris, which were sent from Villa de Medici (Üren, 1938-1939, p. 1); unpublished diary, İmren Erşen Collection, Ankara.)

8 Pierre Dèsirè Guillemet (1827-1878) established Académie de Dessin et de Peinture in Istanbul, in 1874 (Artun, 2007, pp. 39, 41). Turkish Painter Association established the Painting School in 1921, in Çemberlitaş, Istanbul (Güler, 2014, p. 55). Eşref Üren attended Çemberlitaş studio too as he was a student in the Fine Arts Academy (Erşen, 2013, p. 14).

9 Hikmet Onat, one of the masters of Eşref Üren in the Academy and a former student of the school, recalled the pre-republican Academy's drawing classes as follows: Speaking of the state of the Sanâyi-i Nefîse (the Imperial Academy) while we were students there, I am not going to stress how hard it was to practice painting back then. There were neither male nor female nude models. Even the ugliest male model would refuse to get naked. The society was accusing our school teaching how to paint and sculpt of immorality and heresy. It was told that before we enrolled in (1904), a few religious fanatics invaded the school, broke the sculptures, put clothes on some antique molds. You should anticipate the difficulty of the wish to paint in such an environment. Our models were some porters wearing a turban, bearded, and with walrus mustaches. We were only able to paint portraits and sculpt busts. One day, we were so sick of painting the porters, we decided to find a female model even if she refused to sit naked. We found a girl from the gypsy neighborhood, she posed as if she was dancing and as we started to draw, headmaster Osman Hamdi asked for us. He yelled, "Are you all mad, where do you think you are? We live in Turkey, and people will not tolerate this. Get rid of her this minute. God willing you will be off to Europe soon, there you may paint as many female models as many nudes as you like" (Artun, 2007, p. 158). 
Most of the Turkish artists drew their nudes in France in the late $19^{\text {th }}$ century. The Turkish students who went to Paris had several options. As they were international students, some additional requirements were needed in order them to enroll in the world-famous École. And after 1863, international students were not allowed in École. As a result, most of them enrolled in other studios in Paris, for example, Académie Julian or later on in the 20th-century in Académie Lhôte. Or they attended the private studios of the famous masters, for example, JeanLéon Gérôme (1824-1904), Alexandre Cabanel (18231889), and Fernand Cormon (1845-1924) (Artun, 2007, p. 53). Although the variety of choices these students had might have composed diversity, the studios in Paris were mainly a prep-school for students who meant to attend Prix de Rome or the École itself. Because of this, drawing classes between these institutes were not very diverse, at least until the $20^{\text {th }}$-century (Artun, 2007, p. 72).

\section{Eşref Üren and the Imperial Art Academy}

Eşref Üren was enchanted with the art of painting in Bursa, as he was walking around the city, and saw İbrahim Çall painting around the 1910s (Erol, 2000, p. 5). Until he started attending the Academy, he was trying to learn to paint by contacting other artists, drawing, and painting by himself. Figure 1, is one of the drawings he made before enrolling to the Academy. Despite his efforts as an amateur, the first disciplined drawing classes he had was in the Academy. Eşref Üren began attending the courses of the Ottoman Imperial Art Academy, Sânayi-i Nefise Mekteb-i Alisi, in 1921 when he was 24 years old. He enrolled in the Academy in 1925 when he was 28 years old (Erşen and Erinç, 1989, pp. 8-10).

Drawing of Rahmetli Nazlı Hanım (Figure 1) is a rare example of Eşref Üren's drawings before the proclamation of the Republic. The drawing is a profile portrait reflecting a characteristic of the late $19^{\text {th }}$ century. This drawing reveals confusion between fusain and pencil. Üren made this drawing before enrolling at the Academy as he was studying on his own. Nazlı Hanım's headscarf is shaded with fusain. However, Üren used hachures on her jacket.

From the 1920s till 1960s the first year of the Academy was to be spent in the main hall of the building which was full of antique sculptures. Students from all the departments of the academy had to attend this series of drawing classes. Classes were named after this hall, which was called the "gallery". Although Hikmet Onat directed these classes, Üren recalls it was İbrahim Çallı who taught him drawing (Üren, 1970, p. 5). Fusain was the main medium used in the Academy at the time. Üren would rarely use the fusain in his drawings all through his life. He made no comments on this medium in his writings, but one incident is a clue of the absence of the medium. One of the freshmen students in 1924 who became a sculpture master in the academy later, Zühdü Müridoğlu (1906-1992) recollected the gallery lessons and fusain in his autobiography as follows:

The word "gallery" was not a saying, that was heard by a miserable person like me 60 years ago. I learned what the gallery was. It was the studio where the freshmen were going to draw from mold models. I

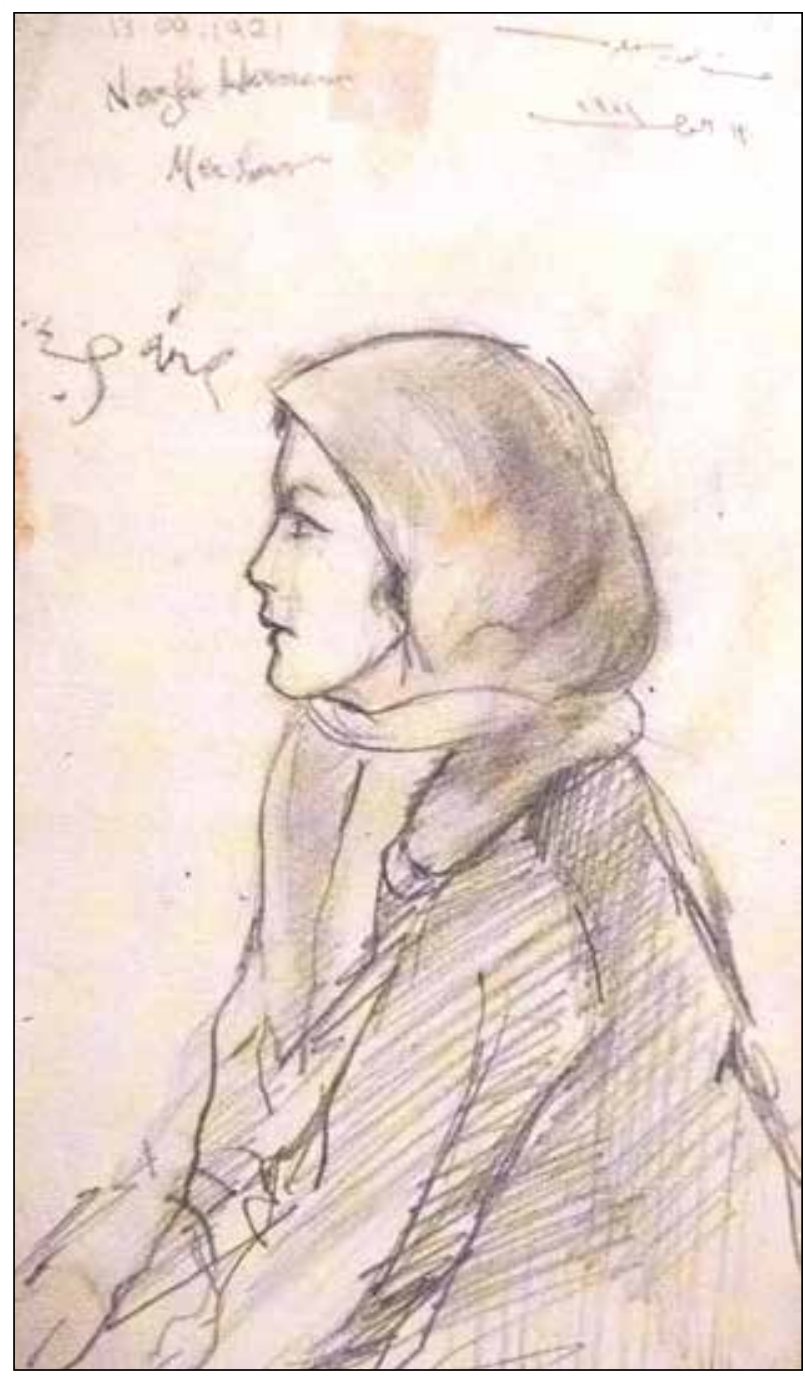

Figure 1. Eşref Üren, Rahmetli Nazlı Hanım, $13^{\text {th }}$ September $1911,19.3 \times 12 \mathrm{~cm}$, pencil on paper. Source: İmren Erşen Collection, Ankara. 
went to this gallery place, and there were three more students. After a while, an older man came in. He was Master Hikmet (Onat). He hung a mold model composed of leaves and flowers on the wall. He said, "Buy Ingres paper and fusain and then draw this," and he went away. We learned what Ingres paper and fusain was, and we bought them, and we started drawing. The object called fusain was a thin willow branch's charcoal. I was not able to use charcoal. Paper, my hands, my face were all in black, and as if it was not enough flowers and leaves were smudged A terrible, dirty thing had come to life (Müridoğlu, 1992, p. 49).

Müridoğlu was disappointed by fusain until he meets Eşref Üren in the Academy. Üren suggested Müridoğlu attends the sculpture modeling studio to improve his drawing (Müridoğlu, 1992, p. 53). Üren's latter drawings will constitute of the outer contours, indicating the form. Modeling studio was a method to understand form in another method. There are no records of Üren using this method, but his suggestion implies he must have thought of this before. Although he is mentioned with his paintings that color touches are heavy, his drawings suggest he had been engaged with the idea of the form, as Müridoğlu's anecdote suggests at least since 1924.

\section{Artistic Encounters of the Republic Era Students in France}

In 1923 Çallı worked hard to get support from the new government to send the students to France in order to study painting. Çallı was successful. The first student group was sent to Europe (Paris and Munich) a year after the proclamation of the Republic in 1924 (Güler, 2014, pp. 102-103). Nurullah Berk was among them with Cemal Tollu (1899-1968), Ali Avni Çelebi (19041993), Zeki Kocamemi (1900-1959).The return of the 1924 group in 1928 is a significant moment for Turkish drawing history. These students who were sent to Paris and Munich attended the studios of French painter André Lhôte and German painter Hans Hofmann. They had taken on post-cubist and constructivist views in Europe. This influence would shape many Ankara paintings and Eşref Üren's Ankara drawings as well.
As a student, Zühtü Müridoğlu recalls that he came across with cubist and constructivist paintings in the Academy library and got confused. However, the return of Zeki Kocamemi and Ali Avni Çelebi from Germany with post-constructivist drawings was more convincing and changed his attitude from rejection to curiosity (Müridoğlu, 1992, pp. 53, 84, 85)..$^{10}$

Müridoğlu's change of attitude was reflected in Nurullah Berk's notes on drawing as criticism. Nurullah Berk, both a student and later a master in the Academy, explained Çallı's drawing skills as follows:

Nazmi Ziya like Claude Monet, like Sisley, had been painting in nature whereas Çallı used to shut himself into his studio, and he would work 'from his mind' as we used to say back then. It was as if looking at the model was depressing for him. He would get rid of the drawings easily, and he would contend with a few sketches when painting a landscape... His drawings were not constructive... His lines were soft and boneless arabesques drawn on the canvas. These drawings were incorrect from the beginning. They were collapsing; they were dissolving (Berk, 1964, p. 7).

A student admitted to the Academy, graduated, then audited again to be sent to Paris and who studied in French painter Fernand Cormon's (1845-1924) studio at least for four years could not have been a failure in the drawing (Güler, 2014, p. 19). Nurullah Berk's recollections of Çallı's drawings reflect that he did not apply classic or constructive drawing views. However, he drew as preliminary works. His drawings are compositions of the figure's outer and inner counters as definite and geometric surfaces. The cross-hachures on these surfaces define light and shaded areas. Thick, medium and thin lines construct a hierarchy to discover light. These qualities are easily tracked in his paintings. The French drawing theories' influences are to be detected to an extent in these works: He applied the geometry that was necessary to reveal the figure as a whole. Hence he would be able to draw a figure that its outer contours are definite, inner

10 Cemal Tollu's drawings from Hans Hofmann studio in the museum are as follows: 1303 6245, 1307 6249, $13106252,13046246,1305$ 6247, 1303 6245, 1306 6248, 1308 6250, 1309 6251. Ali Avni Çelebi's drawings from Hans Hofmann Studio in the museum are as follows: 574 1558, 575 1559, 576 1560. Nurullah Berk drawings with Lhôte's influence in the museum 6282376 . Halil Dikmen drawings with Lhôte's influence in the museum 12032 3852, 12037 3857, 12033 3853, 12039 3859, $120413861,2226864,12042$ 3862, $22048619,22058620,22108625,2211$ 8626, 2225 8640, 2226 8641. Salih Urallı drawings with Lhôte's influence in the museum 23649539. 
counters which reflect details are economical, half-tints applied only to reveal light (Akder, 2015, p. 95). ${ }^{11}$

Nurullah Berk's criticism is indicating the change in the idea of drawing. Berk was to engage in a new drawing tendency, André Lhôte's, and criticize Çallı according to it. We may also claim that Berk's objections were founded by a second encounter with European painting, in the Republican era.

The curriculum of the Academy in 1934 was mimicking the late $19^{\text {th }}$ century École more. Gallery had been maintained, and cours de soir was also added. According to the Academy regulations, students were categorized as primary and semipermanent. During the audition, they had to draw with fusain for six days from a live model. Successful candidates would draw for six more days from plaster molds to finish the audition exam (Üstünipek, 2009, pp. 22-24). However, like the New Republic's political, cultural, and social life, painting was about to change. During the 1930s the dominant view in the Academy is going to change into post-constructivist views. A French painter and an academician with postcubic and constructivist tendencies Léopold Lévy's (18821966) assignment to the Academy backed up changes in the school (Üstünipek, 2009, pp. 53-54).

\section{André Lhôte and Eşref Üren}

Eşref Üren's encounters with European art took place during the Republic era. During his tours to Paris, André Lhôte made a great influence on Eşref Üren's drawings. This influence is apperant on Eşref Üren's Ankara drawings. Lhôte proved to be a big influence on Turkish painting too, as many students attended his studio as an artist and as a teacher- What is more, he wrote books on art theory. One of the students and future masters of the Academy, Nurullah Berk, was a champion of these theories (Akder, 2015, p. 131). Berk spoke of these theories in his essays and books many times over. As a result, Lhôte influenced the students who attended his class, and who knew French but also the audience of Berk who knew Turkish. Lhôte states that the elements of the art of painting are determinant. These are composition, surface divisions, light-dark (chiaroscuro), screens, passages, light, light-color, and drawing (Lhôte, 1950, pp. $5,12,13,16,19,23,25,36)$.
Lhôte praises French painter Paul Valery's (1871-1945) definition of drawing, "Drawing is not form, it's the way of seeing the form". And he tries to explain how an artist could do it. Lhôte's discussion composes between a line surrounding an object, and a line breaks the form outside and inside, allowing passages occur. He warns the draughtsman about the drawings whose subjects are a simultaneous vision rather than one object. He emphasizes that the former needs are organizing harmonious exchanges between all lines, surfaces between objects (as there are no voids nor solids). In Lhôte's opinion, these should be done according to "fixed laws". He strongly claims that copying a form fluidly free from all geometric pretentions is not a good way to draw. A draughtsman just like children should learn that "considering geometry and truth as inseparable and introduce all representation of reality as a game" (Lhôte, 1950, pp. 25-28). As he ends the chapter, he advises making reproductions of trees engraved by Jerome (Gerôme/Hieronymus) Cock (1518-1570), a $16^{\text {th }}$ century, Flemish painter and etcher after drawings by Brueghel. He states the reason as "Each tree is enclosed in a clearly defined geometric figure and rises, opens out, forms shelves or whorls by a very strong emphasized rhythm" (Lhôte, 1950, p. 30).

Lhôte's definition of drawing is the ability to see the form, and "the painting is a means of giving life to the drawing" (Lhôte, 1950, p. 27). Passages are also important to the drawing, which Lhôte defined as: An object receives quality from its surroundings, and the surroundings receive quality from the object, which is called a passage. This interaction appears in painting with chiaroscuro, tones, and half-tints. The famous example Lhôte uses to explain this interaction is an egg which is situated against very dark, light, and medium (grey) surfaces. If the surface is very dark, the most illuminated part of the egg will create a strong contrast against the surface and the nearest parts to the surface will appear grey. If the egg is on a grey surface, the illuminated part of the egg will be smaller, and the parts nearest to the surface will be darker. Should the egg be placed on a light surface, then the egg will almost unite with the surface. And half-tints and the darkest parts will be in contrast with the surface. Hence there is always a connection point of the object to its surface. As a result, if we are to draw an object just

11 The Museum's collection doesn't have any of Çallı's drawings. But Ayşenur Güler's doctoral dissertation is a very ample study of his repertoire (Güler, 2014). Çallı's paintings were a combination of post-impressionist light, color, and naturalistic composition. His repertoire was mainly on portraits, landscapes, and still-lifes. Unfortunately, İbrahim Çallı's oeuvre except for the Ph.D. thesis of Ayşenur Güler has not been analyzed, and his drawings have been neglected immensely. 
by its contours, we would be drawing the memory of the object but not the image in front of us. We need passages and contour to perceive the object correctly (Lhôte, 1950, pp. 16-20).

By the time it was 1927, Eşref Üren was determined to go to practice all these, but he had a very small income. As a result, he had to finance his tours to France by his means. And he did, he sold paintings in the exhibitions organized in Ankara (Özyiğit, 2005, pp. 54, 56).

1927 was the first time Ankara's developing art scenes became imperative for Eşref Üren. After the proclamation of the Republic in 1923, the new government began working on the construction of Ankara as a modern capital. This included supporting artistic efforts in the city, such as organizing annual exhibitions. ${ }^{12}$ After the First World War, the National Forces of Turkey uprose and fought the Independence War. In 1920 the headquarters of the National Forces settled down in Ankara. Just before the proclamation of the Republic, Ankara was the capital city on $13^{\text {th }}$ October 1923. The $1^{\text {st }}$ Ankara Exhibition was opened two weeks before the proclamation. During the Ottoman era, most of the exhibitions were held in İstanbul. But the new government worked hard to make its capital the capital of art as well (Özyiğit, 2005, p. 20). By 1927 the most important annual painting and sculpture exhibitions were held in Ankara what is more most of the painting was also made in Ankara, although the city which had only one Turkish painter who had settled down before the War of Independence (Aras, 2010, p. 14). ${ }^{13}$ These opportunities seem to help Eşref Üren to sell a painting and finance his tour.

On March 1928 Eşref Üren arrived in Paris. He attended André Lhôte's Académie rue d'Odessa (Erşen, 2013, p. 16). Figure 2, dated 1928, was drawn during Üren's first visit to Paris and Lhôte's studio. Üren worked on this pose at least in two other drawings. Üren defined the outer contours of the figure and worked on details on the face. The vertical hachures are the passages. Although the outer contours are mostly uninterrupted, it gets thinner and thicker according to light. The geometrical division is apparent on the face, although the other parts of the drawing seem hesitant. Üren respected Lhôte, however, he never fully gave his paintings to constructivist or postcubist views. On $30^{\text {th }}$ May 1980 Üren wrote:

I have a humble view of art. The art of painting has determinant and transient rules. My dear teacher, André Lhôte, taught these to me. May mighty God be pleased with him. As I am telling this, I haven't forgotten my teachers at the Fine Arts Academy. Master Hikmet, İbrahim Çall, Mr. Feyhaman whom I commemorate. Nazmi Ziya Güran. Mr. Ruhi. Avni Lifij is my spiritual master. I am transposing nature (Erşen, 2014, p. 8).

Üren speaks of his artistic mentors naturally and calmly. But his involvement with André Lhôte's theories proved to be very important. It is important because firstly they changed his style and secondly this style prolonged in

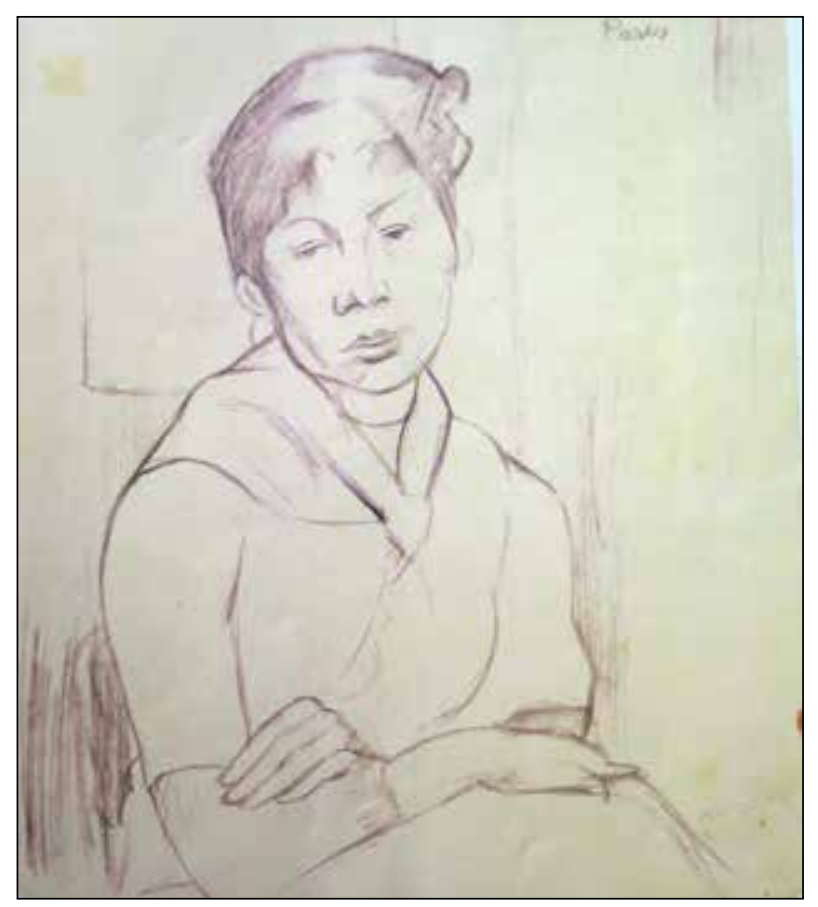

Figure 2. Eşref Üren, from Paris drawings, 1928, pencil on paper.

Source: İmren Erşen Collection, Ankara.

\footnotetext{
12 Before the Republic Ankara was a moderately developed Anatolian city. Between the early 16th century and the first half of the 19th century, Ankara was better off with the commerce of Angora goat yarn and it's a by-product, a textile called sof. The late 19th-century governors of the city tried to develop public works of the city however two years of severe drought, cholera and the wars the Ottoman Empire took part to decrease the welfare of the city and the population of the city drastically.

13 The only painter who settled down in Ankara in 1919 was İhsan Cemal Karaburçak (1897-1970). He was assigned to the Telegram Directorate of Ankara as an officer. He became one of Ankara's famous abstract painters however he started painting in 1930 (Aras, 2010, pp. 14, 20).
} 
his life. This is much clearer in his drawings than his paintings. At first, the criticism that Üren got from Lhôte was upsetting, then he started to get better criticism. Hard work in the studio, museum visits, drawings, sketches, and oil paintings was proving to be satisfactory for him (Erşen, 2013, p. 16).

When Üren returned to Turkey, he was assigned as an art teacher in a middle school and went to Erzurum, Eastern Anatolia to carry out his duties. In 1934 he was assigned to work in Sivas (Erşen and Erinç, 1989, p.13). He continued to paint and draw in these cities. One of the drawings, most likely a colleague from Erzurum sat for him on $5^{\text {th }}$ November 1933 (Figure 3). At first glance, it is as if Üren completed the drawing without ever detaching his pencil from the paper, and this is a falling out from Lhôte's theories. But as the lines get thicker and thinner, they create breaks, hence passages. Curves which will be very dominant in Eşref Üren's Ankara years appeared, and we may easily say that he grew a liking towards curved lines defining the form.

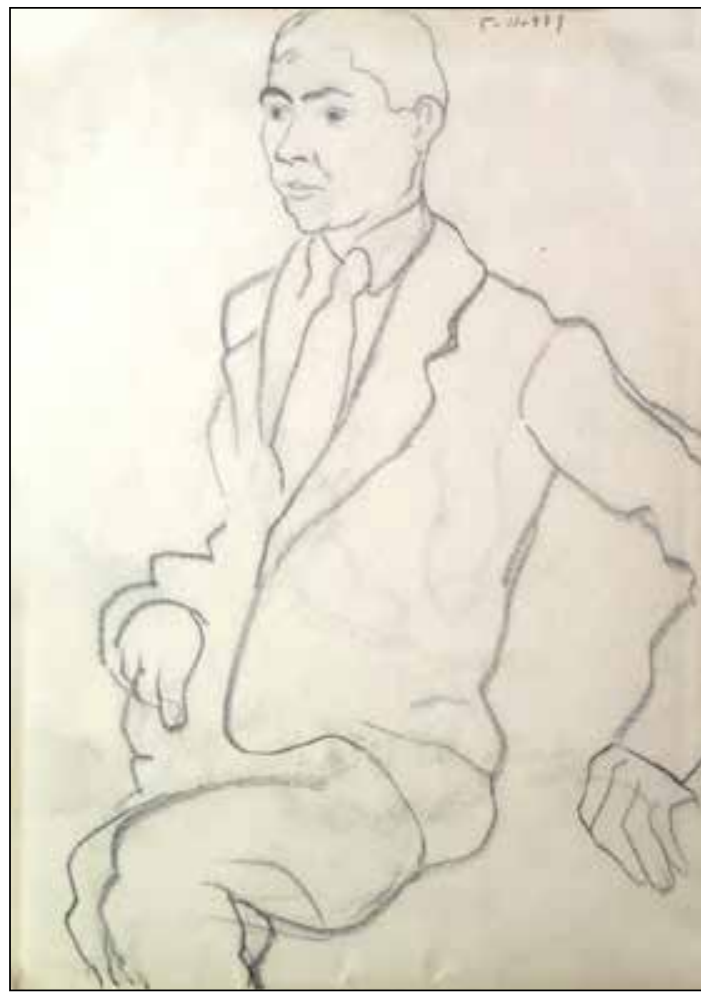

Figure 3. Eşref Üren, from Erzurum drawings, $5^{\text {th }}$ November 1933, pencil on paper.

Source: İmren Erşen Collection, Ankara.
As Üren was engaging with modern art during the 1930s, he also made imitations from the old masters. Figure 4 is an example that shows Üren made imitations from the old masters such as $15^{\text {th }}$ century German painter, Hans Holbein (1497-1543). Old Master drawing studies of Eşref Üren seems to be more influential before 1945. Cavalary Riding into the Village exemplifies this influence in an Ankara drawing which will be explained later. Museum collection proves that many of the 51 artists whose drawings are in the museum collection also made imitations from the old masters. These efforts could be listed as the direct effects of cultural encounters with European art.

In 1938 with his wife Melahat Üren (1918-1969) who is also a painter, Üren went to Paris for the second time and again attended André Lhôte's studio. During his second visit to Paris, Üren kept two diaries. On $10^{\text {th }}$ October 1938, he began attending André Lhôte's studio. In the mornings, he would go to the museums, and in the afternoons, he would attend the drawing classes at Academié Lhôte (Erşen, 2013, p. 18).

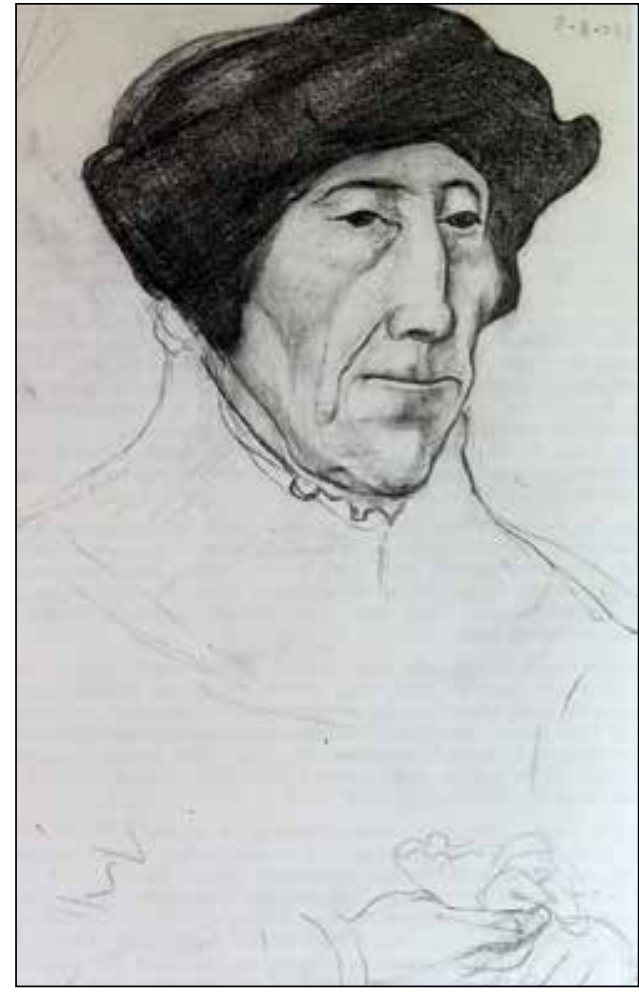

Figure 4. Eşref Üren, copy from Hans Holbein, $8^{\text {th }}$ August 1933, 23.5x14 cm, pencil on paper. Source: İmren Erşen Collection, Ankara. 
Eşref Üren drew a portrait on $21^{\text {st }}$ April 1939, in Paris (Figure 5). This drawing reflects André Lhôte's teachings very well. There are no curves if the form is not a circle, like the bun of Mrs. Üren. On the areas where half-tones were applied, the contour lines are thin as if they are dissolving, like the back of the head and brim of the hat. Or just under the chin, near the mouth. There is not a powerful direction of the light source. When we compare this drawing with the matching painting, it is easily seen that Üren used the drawing as preliminary work. ${ }^{14}$ Red, yellow and orange half-tones are applied to the areas that are the lightest in the drawing; purple and blue to the darkest. Hachured areas are not missed in the painting as well as colors interaction with its surroundings is carefully thought. Lhôte emphasized the difference between curved and geometrized lines (Lhôte, 1950, p. 27). These efforts were exact applications of Lhôte's theories. Eşref Üren drew in this manner also in Ankara when a model and a studio were available to him.

Parisian life on the eve of the Second World War was productive for Eşref Üren. Cemal Tollu, an old friend from the Academy, visited him. On $21^{\text {st }}$ July 1939, Cemal Tollu arrived in Paris. Together they had a wonderful week. They went to the French painter Marcel Gromaire's (1892-1971) studio, came across with French painter Fernand Legér (1881-1955). They visited Louvre, Luxemburg Museum, Musse Guimet, Musse Cluny together. They also draw sketches in Champs-Élysées and Luxemburg Gardens. On $22^{\text {nd }}$ August 1939, Üren started to write about the war (Üren, 1939, pp. 25-36). They had to leave Paris eventually on $23^{\text {rd }}$ September 1939 . As they came back to Turkey, the Üren couple settled down in Ankara (Erşen, 2013, p. 18).

\section{Eşref Üren and the Modern Capital Ankara}

Ankara is the city where Üren matured his art and lived for 45 years, until his death in 1984 . The city with its parks, boulevards, crowds, iconic buildings, and streets was among his main subjects which all came to life as a part of the construction of Ankara. His favorite place of painting was Kurtuluş Park, which was between his home and his school, where he was an art teacher (Figure 6, 7). As he settled down in Ankara, in 1939, he was on the edge of maturing his art. He was 42 years old, had attended Paris studios twice, had been providing his livelihood as an art teacher for nine years, and he had been experimenting on the classical drawings, post-impressionist drawings

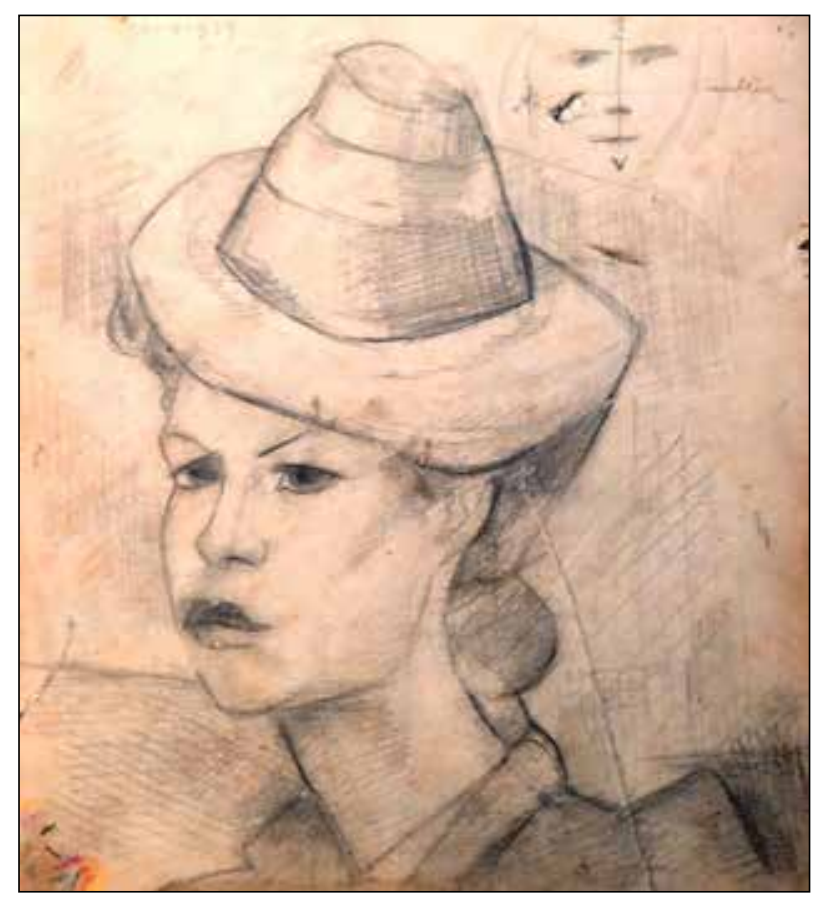

Figure 5. Eşref Üren, Portrait from Lhôte Studio, $21^{\text {st }}$ April $1939,20.5 \times 18 \mathrm{~cm}$, Pencil on paper.

Source: İmren Erşen Collection, Ankara.

and post-cubist drawings since 1921. Consistent with paintings in his drawings pads of the coming 45 years, majority of the drawings belong to landscapes and cityscapes. He used to stroll around his neighborhood as he had a pad in his pocket and drew on foot. He had walking routes, on which his wife Melahat Üren who was also a painter accompanied him.

In his drawing pad named "notes of 1941", he listed the places he had been to paint and draw (Figure 8). Cebeci Street, Dilektepe, Kutlu Patisary, Özen Patisary, Bear Park in Yenişehir, Fidanlik, Floor Mill, Train Operations Place, Towards Gas Factory, Towards the College of Languages, History, and Geography, Towards The Exhibition Hall, From İçcebeci were the paintings he completed in 1941. Names of the paintings are districts in the city, and they signify a route. The route starts from Cebeci and goes towards Ulus where Özen and Kutlu Patisary were opposite to each other. From this spot, the path leads to Kızılay or Yenişehir from Sihhiye where the College of Languages, History, and Geography and The Exhibition 
Hall stands. And from Sihhiye to Kızllay or Yenişehir Beer Park. Üren could use several streets to go back his home, to Uğurlu Sokak, İçcebeci where his home was. Had he chosen he could have lengthened his path walk to Maltepe district from Kizılay about 20 minutes more, and see the Gas Factory. In 1941 the $3^{\text {rd }}$ State Painting and Sculpture Exhibition list points to a route of 80 or 100 minutes of walking, almost in a circle in Ankara. This circle's center is Kurtuluş Park, near his home.

\section{Eşref Üren's Manner of Drawing}

Eşref Üren's manner of drawing and painting in Ankara reminds of another Turkish painter and a very capable draughtsman, Hoca Ali Riza. Üren never met Hoca Ali Riza according to records we have today. Üren's recollection of Hoca Ali Riza is the drawing manual that was published by the Imperial Military Academy Publishing House. Üren wrote sentimentally about this manual:
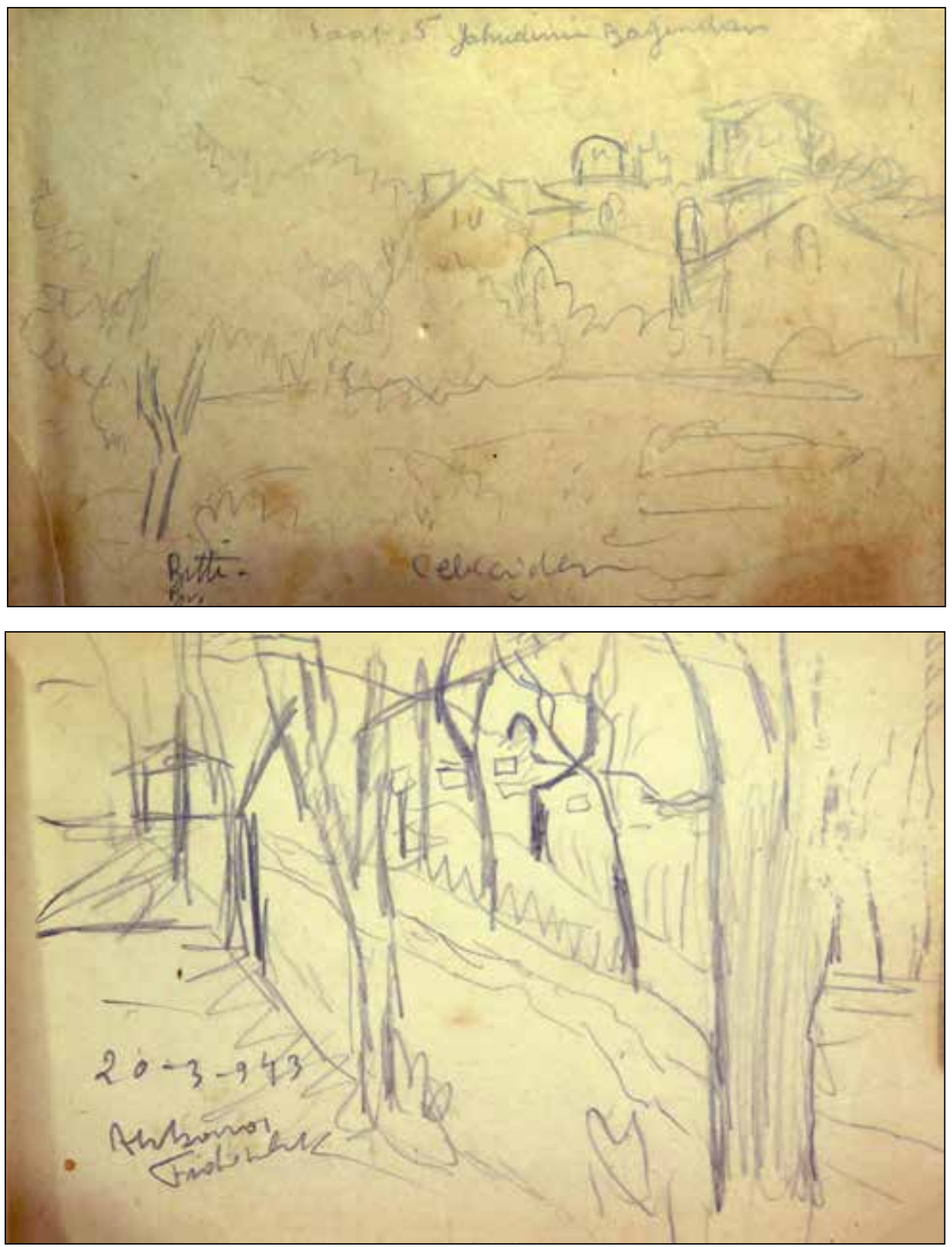

Figure 6. Eşref Üren, Yahudi'nin Bağı, Cebeci, $1941-1943,14.2 \times 8 \mathrm{~cm}$, pencil on paper.

Source: İmren Erşen Collection, Ankara.
Figure 7. Eşref Üren, Ankara Fidanllk, $20^{\text {th }}$ March 1943, $14.2 \times 8 \mathrm{~cm}$, pencil on paper. The area where Kurtulus Park1 is constructed on had been called and used as Fidanlik (nursery) before it was planned as a park in 1960 (Burat, 2011, p. 121). Source: İmren Erşen Collection, Ankara. 
The first love of our generation is the late Hoca Ali Rıza of Üsküdar's lithographies printed in the Harbiye Publishing House. They were our generation's, we who had never seen anything other than bad photographies, experiences of tasting an art piece which was hand made. We were caught by the magic of the monumental cypresses of Karacaahmet (graveyard), burnt voices of women coming out of the Üsküdar houses' oriels with those lithographies. Master became the otherworldly, Muslim Üskudar's, and Bosphouros's gliding sailboats artist. The best image of Hoca Ali Riza was told by Turgut Zaim. He said Hoca Ali Riza was the Corot of Turks. Later Alex Calame's printed drawings were the forces that pushed us into painting along with Hoca Ali Riza's works (Üren, 1971a, p. 6). ${ }^{15}$

Hoca Ali Riza drew while he was walking on the hills and coastline of İstanbul (Anatolian Coast, from Üsküdar towards Beykoz). ${ }^{16}$ These drawings were most likely artistic notes taken rather than being preliminary sketches. Although in drawing classes in the Academy and École late $19^{\text {th }}$ and early $20^{\text {th }}$ centuries it was common to use the fusain; Hoca Ali Riza preferred pencil. He never mentioned a reason. But the classes he attended both as a student and a teacher in the Military Academy were based on classes named hachures which were applied with a pencil. Unlike the rest of the museum collection figure drawings of Hoca Ali Riza are rare. Some of the drawings, especially in the drawing pad no 1 , are the preliminary sketches of the drawing manuals (Akder, 2015, pp. 77-78).

Eşref Üren mentioned Hoca Ali Rıza with his drawing manuals. These are important as they are the documentation of Hoca Ali Riza and the military school's views of drawing as well as they had a widespread influence of the Turkish artistic circles as Eşref Üren mentions. The foundation of the manuals was a report Hoca Ali Riza drew up a report about drawing lessons in Harbiye in 1889. This is the most efficient documentation of Hoca Ali Riza's conception of drawing classes along with the recollec-

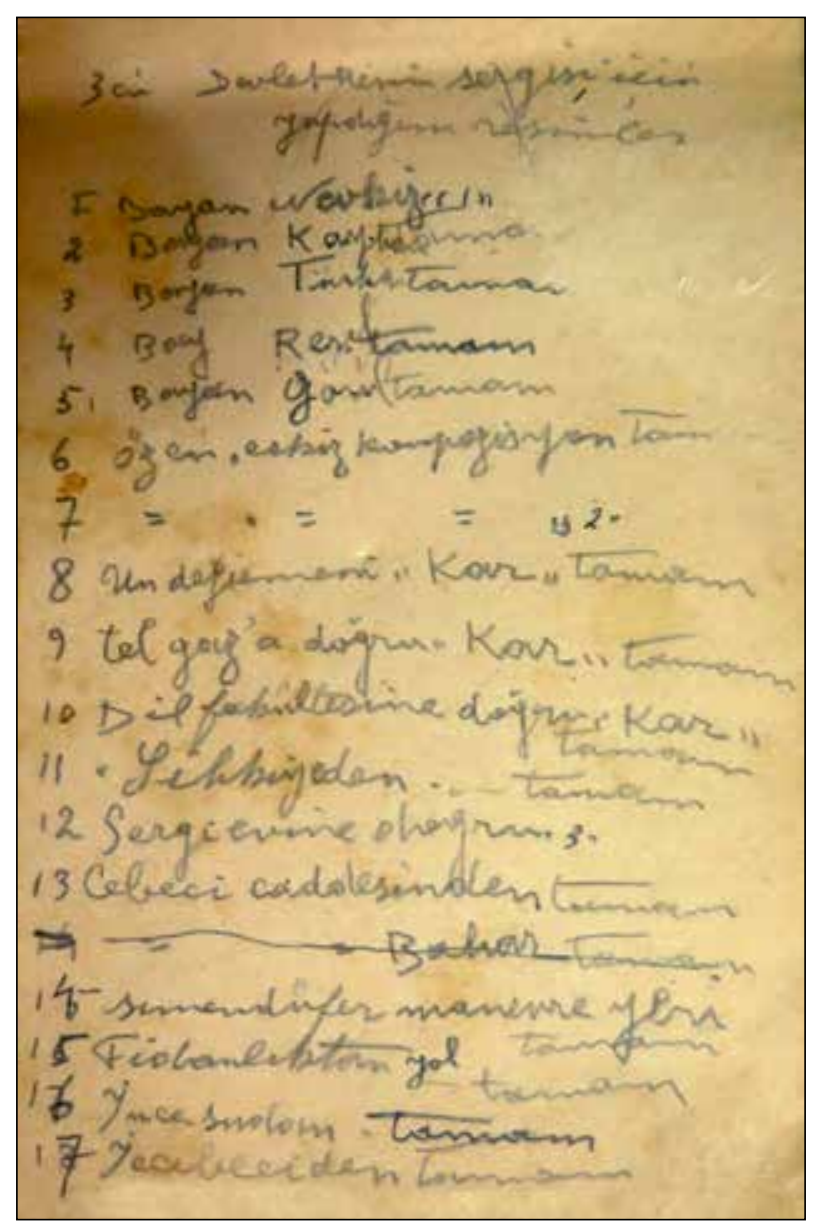

Figure 8. List of paintings exhibited in the $3^{\text {rd }}$ State Painting and Sculpture Exhibition, from Eşref Üren's drawing pad named "1941 notes EÜ", 1941-1943, 14.2x8 cm.

Source: İmren Erşen Collection, Ankara.

tions of his students, which is very rare. The report argues that some methods of traditional Ottoman calligraphy classes could be beneficial to drawing classes at least in the beginning. While all the Ottoman art education institutes and educators embraced a western-style in art

15 Eşref Üren used the Turkish phrase "ilk göz ağırısı" (first pain of the eye) in the first sentence. There is no equivalent in English for it and the present author translated it as "first love". This phrase means a first experience with some engagement or a person loved deeply in which one had to work hard to succeed in this relationship, for example the first child of the family or the first students of a teacher. The graveyard of Karacaahmet in Istanbul is a very large graveyard that started working in the $17^{\text {th }}$ century. Turgut Zaim is a Turkish painter, classmate and, lifelong friend of Eşref Üren.

16 Hoca Ali Rıza's drawings in the National Library Collection has lots of scenes from Beykoz, Çamlıca, Anadolu Hisarı, and Üsküdar. Hoca Ali Riza drawing pads in the Museum do not signify a change in technique or perception of the landscape. It is rather hard to match Hoca Ali Riza's drawings to a single oil painting of his. 
education; Hoca Ali Riza suggested an eclectic method. The reason for this suggestion must have been Hoca Ali Riza's first master; his father was an artist of the calligraphy (Hoca Ali Rıza, 1967, p. 5).

It is never possible to deny the degree of perfection of the method of d'après nature method of senior high school students in different classes. In so far as, for these students to benefit from this well-accepted method effectively and adequately, it is clear that the foundation of this lesson should be enforced with a solid method. And, this signifies that book that might be named Drawing Manual (Rehber-i Tersim) should be used like Turkish Calligraphy, Manual for Children (Hüsn-i Hatt-ı Türki, Rehber-i Sibyan). In this book, the fundamental lines, such as horizontal, and vertical could be shown. And after horizontal lines curved or bent lines might be emphasized according to their positions such as above and below. And various ellipses, bent lines, lines forming corners, geometric shapes, crooked lines, and toothed lines could be shown. These could be distributed according to the number of lessons for different hours. And some manuals including some simpler shapes from the mind should be thought to students in the first year of Military Junior-High School (Askeri Rüşdiye Mektepleri). Students, just like the calligraphy classes, retrace the forms that have been designed in mind. And as such, through an intensive study drawing methods (Kiziltoprak, 2012, s. 119).

This report is also a new model of drawing. Accordingly, to his report, after his assignment to the chief painter in Imperial Military Academy Publishing House, Hoca Ali Riza drew and printed three manuals with 30 models for military schools (Erhan, 1980, p. 39).

In 1941, Eşref Üren started keeping his first drawing pad that we know. ${ }^{17}$ Üren's manner of drawing by strolling is apparent in all drawings pads he kept in Ankara. A year later on Ülkü Journal's cover on $1^{\text {st }}$ September 1942, a drawing by Üren was published (Figure 9). Drawing's title is Cavalry Riding into the Village. Üren painted at least two paintings relating to this drawing. The painting's title was National Forces Riding into Ankara. ${ }^{18}$
As we mentioned before, Lhôte advised making imitations of Jerome Cock's work after Breughel Brueghel (Lhôte, 1950, p. 30). He chose tree drawings to support both his drawing and determinant theories. Cavalry Riding into the Village is a drawing that supports the idea that Üren took Lhôte's advice. ${ }^{19}$ Tree and sky details of Jerome Cock's engraving of Cephalus and Procris are both similar to Lhôte's text and Üren's drawing (Figure $10 \mathrm{~A}, \mathrm{~B}$ ). The tree on the right is the darkest area, and the medium is

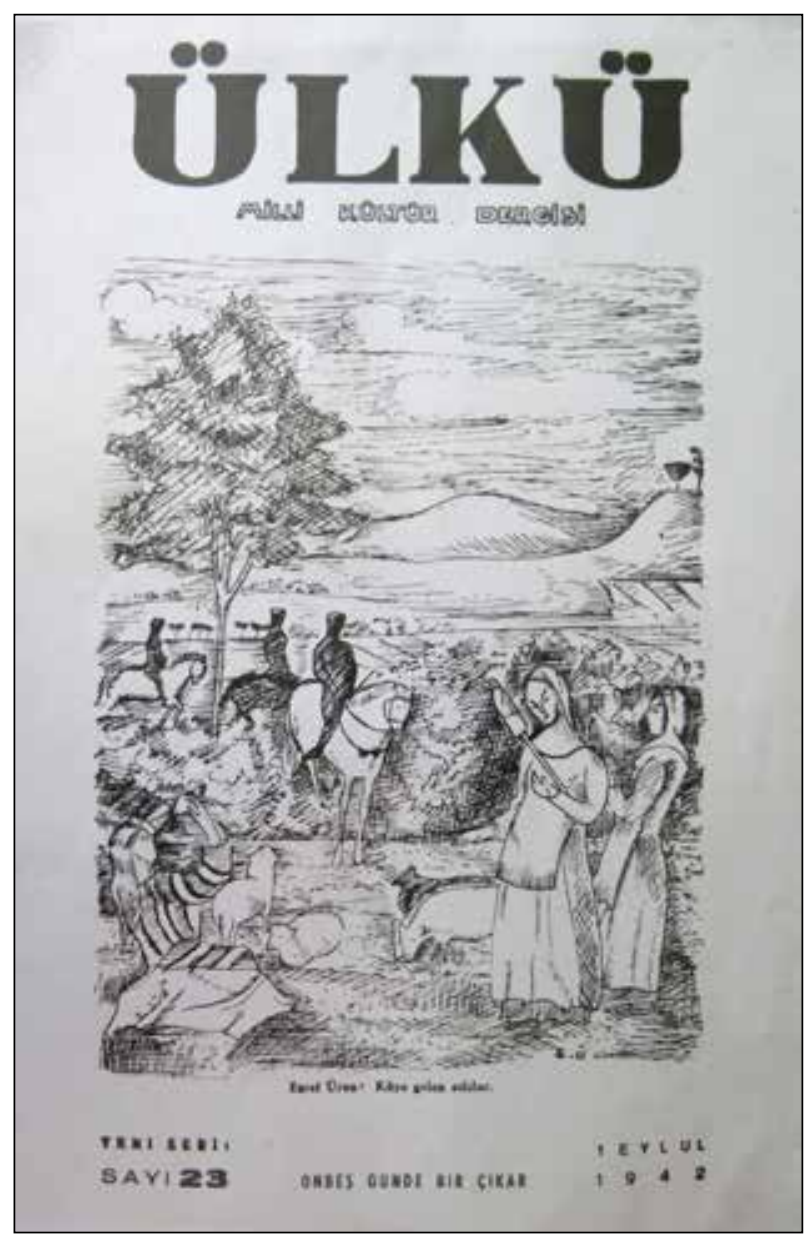

Figure 9. Eşref Üren, Cavalry Riding into the Village, Ülkü Journal Cover, $1^{\text {st }}$ September 1942, New Series, Issue 23. Source: İmren Erşen Collection, Ankara.

17 He used to give his paintings as gifts a lot. As a result, it is very hard to deduce the exact number of paintings and drawings he made.

18 Eşref Üren told the title of the painting to İmren Erşen, as she was taking notes of his biography. These notes have not been published yet.

19 On the letter dated 14th January 1943, Cemal Bingöl reminded Eşref Üren that he had given the Lhôte book he commissioned and Bingöl gave the books to Suut Kemal Yetkin for safe keeping. Although the name of the book is not mentioned in the letter this signifies Üren still cared for Lhôte (Bingöl, 1943, p. 1). 
the sky. The lightest areas are the white areas on the tree as if a beam of light had fallen on. Curved lines of the clouds and the horizontal lines defining the sky are the effects of the same drawing affiliations. The rest of the figures and relationships of the surfaces between them are also composed of interrupted lines and passages. This is an application of the practice of old masters into a new frame, through Lhôte and the new cultural policies of the Turkish government.

Cavalry Riding into the Village is a historical composition pointing to 1920. Üren represented Ankara with Angora Goats and yarn spinning women. This peaceful scene is sui generis. The paintings in the Republican era generally represented Ankara's involvement in the Independence War and the National Forces with Mustafa Kemal Atatürk's encounter with the Ankara Seymens in Dikmen area.

\section{Art Circles in Ankara}

Eşref Üren's choice of theory should have enabled him to get by the main artistic trends in Turkish artistic circles. As most of the students came back to Turkey in 1928 were now academicians in the Fine Arts Academy, during the 1940s. Between 1928 and 1939, they had established two artistic groups that had post-cubist and constructivist tendencies. And Nurullah Berk, who acted as the spokesmen of these groups pointed André Lhôte's theories as to the foundation of their paintings (Yasa Yaman, 2002, p. 24).

Nurullah Berk's drawings in the Museum also point out the effects of lines, the relationship between surfaces and passages as advised by Lhôte. Berk was a founding member of the d Group. In 1933 they had their first exhibition with drawings. This was a first in Turkish art history (Berk, 1943, p. 75-81). Cemal Tollu, Ahmet Zeki Kocamemi, Halil Dikmen (1906-1964), and Salih Urallı (1908-1984) are the painters that have such drawings in the museum collection. Although the source of the tendency seems to a person, André Lhôte, all of these painters used these theories in different ways, which led to a variety. After the 1950s, their styles would be very different from each other (Akder, 2015, pp. 133-136). Eşref Üren's choice was on the interruption of the lines, form, and surface arrangements hence the composition. Despite all the similarities, Üren never got applause from these academic circles all through his life.

During the 1940s Ankara was developing in the artistic sense. There were three professional exhibition halls in the city, four annual exhibitions were taking place in Ankara, and most of the art sale was made in this city. Still due to many reasons and mostly the Second World War, living in Ankara was insufficient in many ways. Although the public opinion on nude paintings was not as offensive as it was in the Ottoman era, it was still a problem to find a working studio with a nude model in it. Cemal Tollu quoted in one of his essays printed in $\ddot{U l k} \ddot{u}$ Journal as follows:

Apart from the ones in the Findiklı Palace (the Academy building), we are not acquainted with a painter who owns a working studio and means to work with a model. I know it very well that for many a studio is a gloomy room of a wooden house; an easel is a bent wall and a dangerous floor to walk. The artist wishing to observe his work from a distance regains consciousness from all the poverty and tiredness as he hits his head to the other wall (Tollu, 1935, p. 123).

As a result, artists who settled down in Ankara attended a studio that was established in Ankara Halkevi (Anonymous, 1942, p. 5). The professional artists would be able to work with live models on Thursday, Friday, and Saturday, what is more, there would be painting and drawing classes for the people in this studio (Anonymous, 1935, p. 47; Anonymous, 1937, p. 12). Eşref Üren was regularly working in this studio (Eyüboğlu, 2015, p. 169). Üren drew Figure 11 in Halkevi. He tried to determine the form using light and dark with cross-hachures and very thick contours reminder of Callı's drawings and his 1911 drawing. In 1951 these institutions were banned due to some series of political events, leaving the artists on their own to solve their problems (Toksoy, 2007, p. 129).

Up to this point, Eşref Üren made both figure painting and drawings as well as landscapes. There is no certain date or a record of why or how Üren gave himself to the landscape. After the 1950s, Turkish paintings started to change as well. Abstract painting and sculpting was the main topic of discussions until the 1960s. Üren was against it. Although abstract art and in the 1960s new expressionist figure painting prevailed, Üren kept to his style and subjects he matured until 1950s.

\section{Eşref Üren's Ankara Drawings}

Even though Üren was drawing as he was strolling, his choices of subjects are not coincidental. The Racetrack of Ankara, Atatürk Boulevard, Güven Park, Fidanlık (Kurtuluş Park) were built during the construction of 

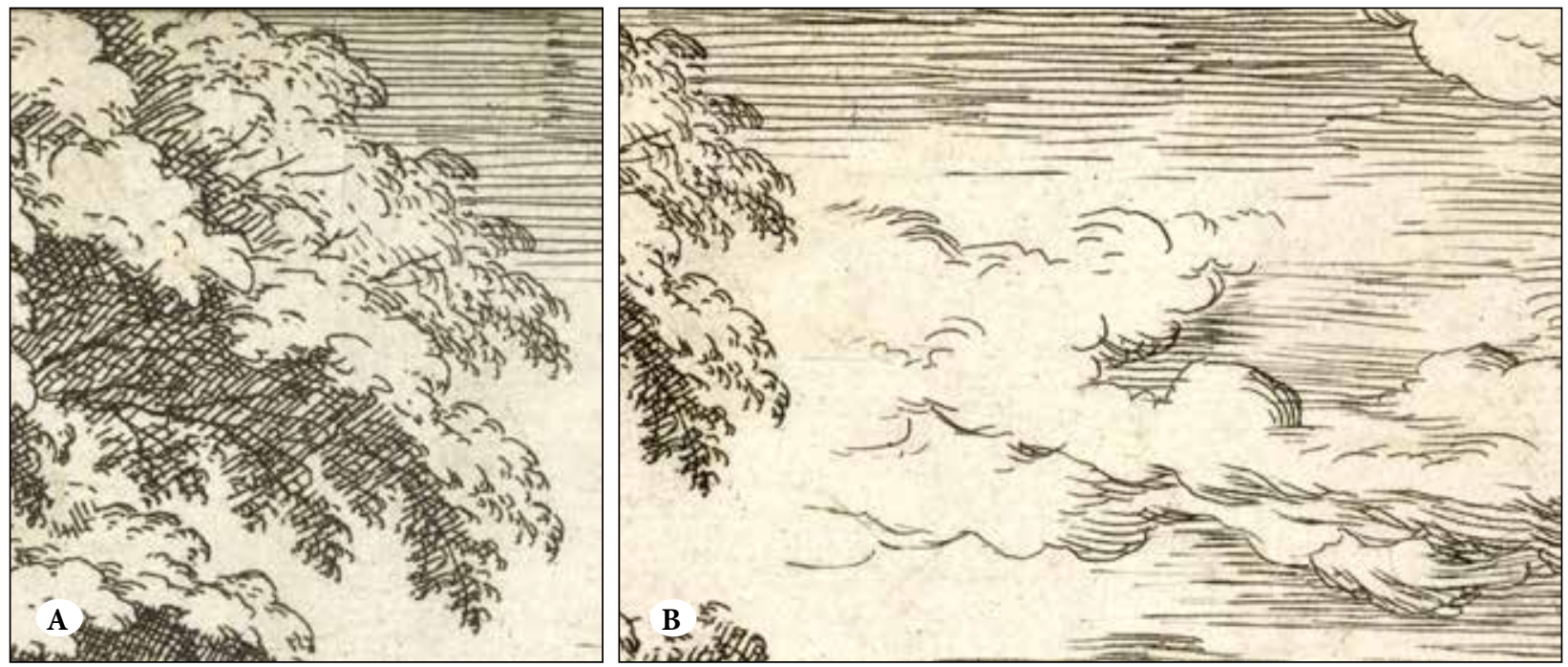

Figure 10A and 10B. Hieronymus (Jerome) Cock, Cephalus en Procris Landschappen met bijbelse en mythologische scenes-details, 1558, etching on paper, $21.8 \times 30.5 \mathrm{~cm}$.

Source: Rijksmuseum, Amsterdam, Inv. no: RP-P-1886-A-10352.

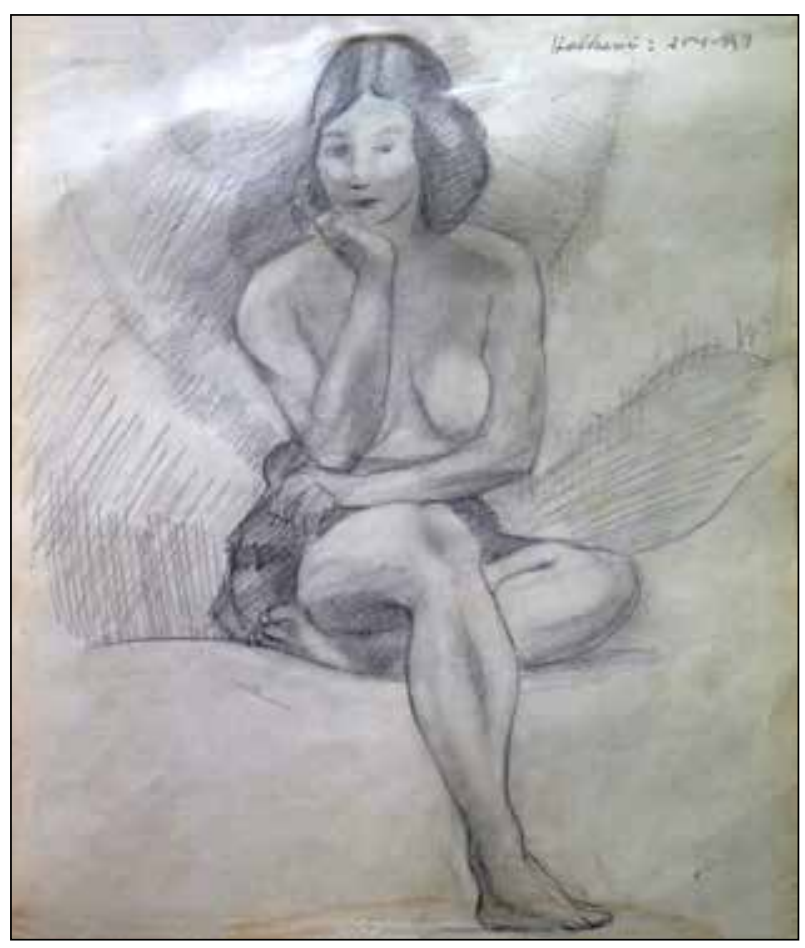

Figure 11. Eşref Üren, From Ankara Halkevi Drawing, $25^{\text {th }}$ January 1943 , pencil on paper.

Source: İmren Erşen Collection, Ankara.
Ankara. They were examples of modern architecture or recreation areas. And they were new social places and buildings that modern city life could flourish in (Bayraktar, 2016, p. 72,73,78). Üren included in his cityscapes these modern recreation areas and buildings.

Eşref Üren never drew or painted in detail. This supported the comment that he was a naive, impressionist painter who emphasizes his impulses rather than training and art theory, along with his references to impressionist artists in his writings. However, Üren was following the path Lhôte drew. According to Lhôte, a draughtsman should draw with representative symbols rather than superimposing the image. Lhôte explains the importance and advantage of using representative symbols as follows:

The draughtsman careful about organizing his representative symbols on the page or panel will, therefore, be led by his careful management of harmonious exchanges between all the lines to give as much interest to what is between the objects as to the objects themselves. For him, here are neither voids nor solids, but surfaces which require, to ensure delectation of the spectator, an arrangement in a certain relationship; analogies and differences must be measured according to fixed laws (Lhôte, 1950, p. 26). 
On the other hand, he took notes about what time it was on his drawings until the 1950s. This act is neither recommended nor rejected by Lhôte. Figure 6 is an example of it. Notes on the drawing indicate that it was five pm when Eşref Üren drew. This is an act of defining the light of the day. This is, in fact, an impressionist gesture. Drawing is very economical. Üren defined outer contours and the main characteristics of the architecture.

Eşref Üren used representative symbols in his drawings. Such as cars, figures, trees, and clouds as well. The reason for this choice was most likely to define the correct position of color in the painting he was going to paint after the drawing.

For Üren, some of the landscape was a distant direction. He mostly named them using the preposition "towards" in his paintings. In such paintings and drawings, he kept his distance from the named area. This manner is similar to the drawing of the nude figure. To see the form as a whole, Üren observed from a distance. The form of the cityscape hence is composed of the topography and human-made structures in his paintings and drawings. Üren's city-scapes often treat the trees and parks in the city as nature. The drawing of Racetrack of Ankara is a good example of this (Figure 12). The Racetrack in Ankara was built in 1936 by an Italian architect Paolo Vietti Violi (1882-1965). The Racetrack was in Ulus area, and it became a new meeting point for the city elite where the horse races and official ceremonies took place, such as the anniversary of the proclamation of the Republic (Alpagut, 2017, p. 928; Bayraktar, 2016, p. 78). From the observation point of Üren, Ankara's famous silhouette with the Ankara Castle is seen. Üren only drew the flagstick of the racetrack which resembles a thin tower.

The Ankara Castle's main gate, Hisar Kapısı was a popular subject to paint for the painters who settled in Ankara. Üren took lots of notes on the drawing (Figure 13), which were written in the Arabic alphabet. Most of these scripts are names of colors. The notes on the drawings such as completed (bitti), oil-painting (yağlboya), and color names written with the Arabic alphabet points to this explanation. Lhôte also dropped some notes about defining the correct place to put paint in a drawing:

To determine the exact spot where color should make its voice heard most strongly, the pictorial elements, which in their obvious arrangement constitute banal reality, should be separated and arranged in a certain way. These elements are light, half tint, and dark; the ornament (elements of the drawing) (Lhôte, 1950, p. 27).

Üren never rubbed his pencil strongly against the paper, especially as he was strolling. First of all, he was meticulous about painting and drawing materials. Secondly, while walking as he sees a sight that challenges him, he would stop, take out his pad, draw on foot, and continued walking. As a result, he must have been

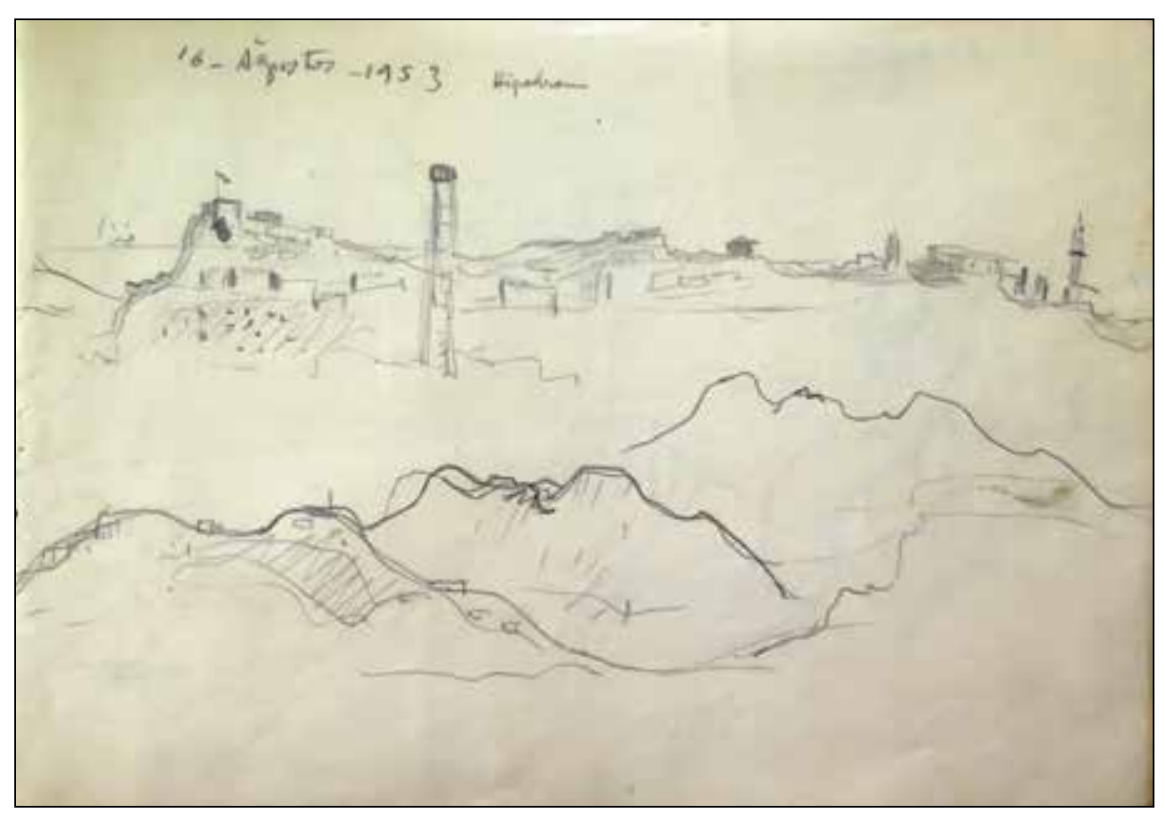

Figure 12. Eşref Üren, Racetrack, $16^{\text {th }}$ August 1953, 19x27.5 cm, pencil on paper.

Source: İmren Erşen Collection, Ankara. 
drawing very quickly. These create a pale effect even there are dark, medium, and thin lines. Figure 14 is the drawing of Atatürk Boulevard. There are several Boulevard paintings of Üren which have not been dated and might be painted in the late 1940s. ${ }^{20}$ But the first definite Boulevard painting of Üren is recorded in 1953, in the list of $14^{\text {th }}$ State Painting and Sculpture Exhibition, numbered as 205 (Anonymous, 1953, p. 10).
Atatürk Boulevard is the main axis of the city. It started from Ulus and led to Çankaya. And the $20^{\text {th }}$ century city's sociology is shaped through it. The main center of the city was Ulus in 1923, then after 1950s Kizllay became the main center until 1980s (Bayraktar, 2013, pp. 21-29). Üren painted, drew, and wrote about the Boulevard. Eşref Üren loved the Boulevard, and many of his drawings are
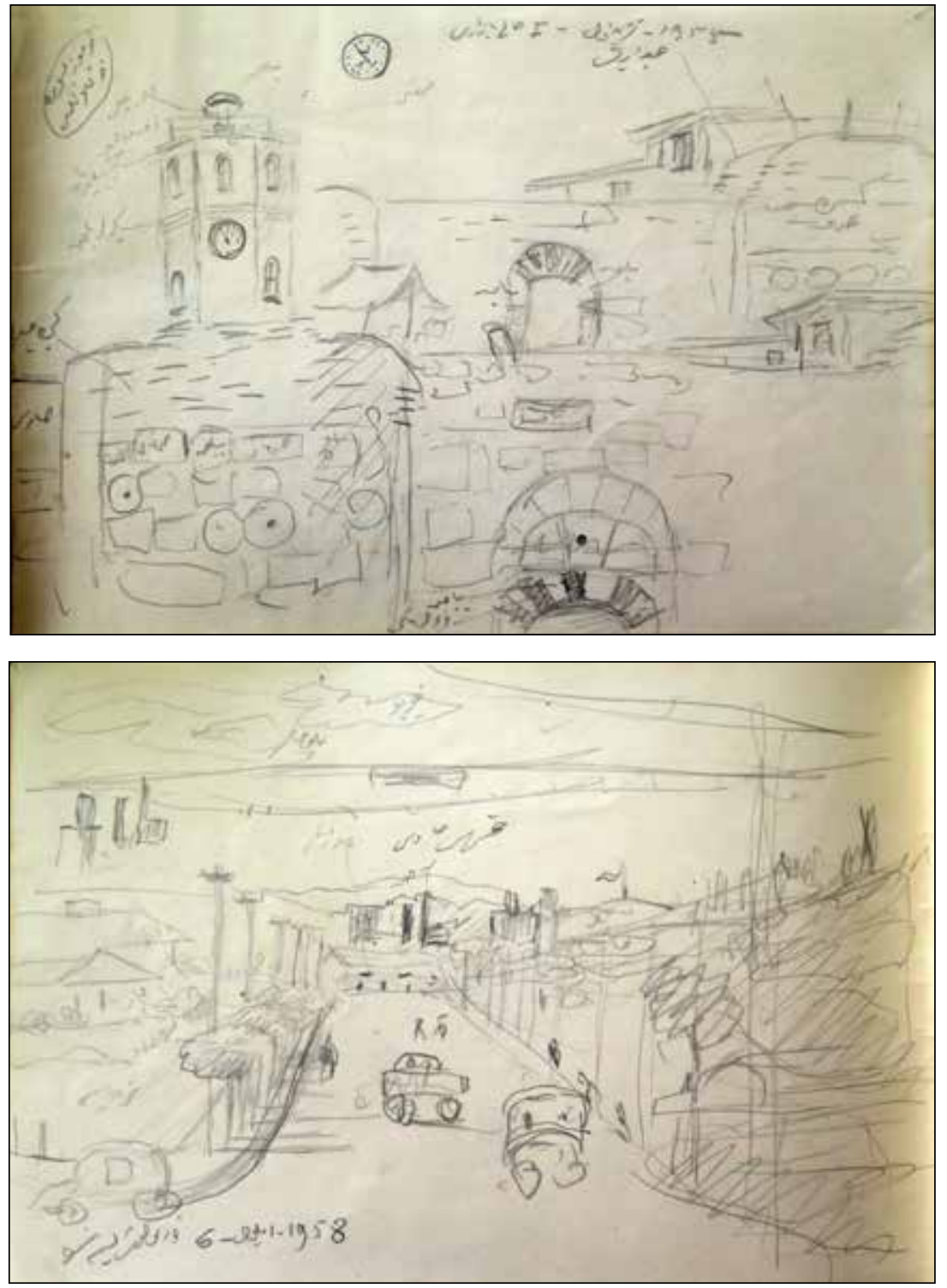

Figure 13. Eşref Üren, Ankara Clock Tower and Castle, $16.5 \times 24 \mathrm{~cm}$, 1955 , pencil on paper.

Source: İmren Erşen Collection, Ankara.
Figure 14. Eşref Üren, 1958, $16.5 \times 24 \mathrm{~cm}$, Pencil on paper. Source: İmren Erşen Collection, Ankara.

20 This painting which is titeled Ankara'dan, $46.5 \times 55.5 \mathrm{~cm}$, oil on cardboard, is in the Museum collection. Eşref Üren, Ankara'dan, (Özsezgin, 1996, s. 365). 
from around it (Figure 16, 17, 18, 21, 23). The Boulevard in his drawings gives the sense of going ahead, towards a point since he uses perspective. The crowd and movement surrounding this continuous asphalt gave him joy. In 1970 he wrote "Boulevard, bathed in the sun, glittery, full of figures! It reflects the joy of life (joie de vivre) of the Impressionists, of Claude Monet" (Üren, 1970, p. 5).

Eşref Üren created rhythm with zigzag lines as if he was doodling. The doodling jest in the Boulevard drawings in the surroundings of the asphalt. This jest is serving for two reasons: first rhythm and second surface divisions, which were also essentials to Lhôte (Lhôte, 1950, pp. 6, 26).

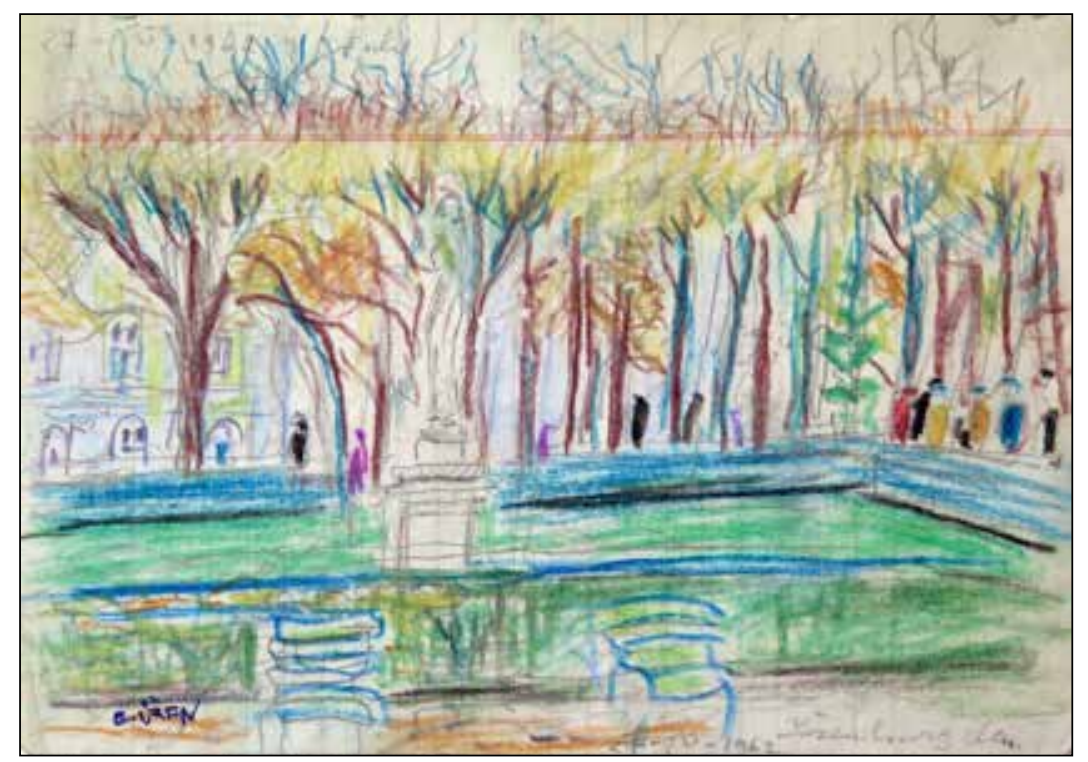

Figure 15. Eşref Üren, From

Luxembourg Gardens, $15.5 \times 22 \mathrm{~cm}$, $27^{\text {th }}$ September 1962 Tuesday, colored pencil on paper.

Source: İmren Erşen Collection, Ankara.

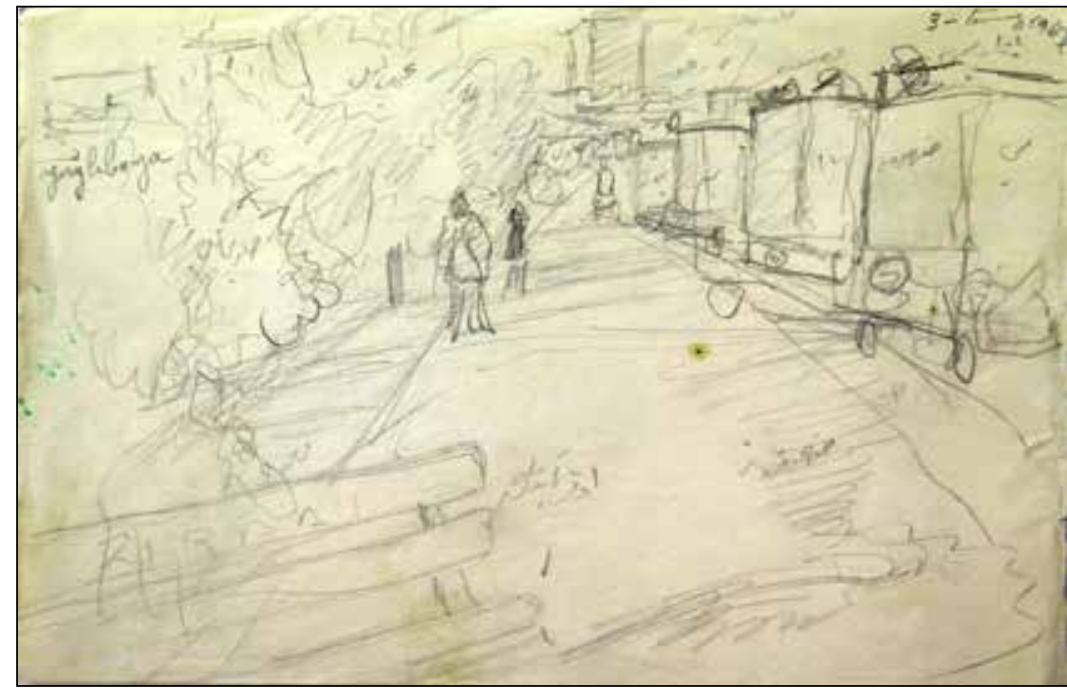

Figure 16. Eşref Üren,

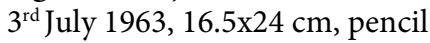
on paper.

Source: İmren Erşen Collection, Ankara. 
1962 Saturday, he drew, and on Monday he went to the same sight to color the sketch according to the notes he took on the drawing (Figure 15). These are the most cheerful drawings in his repertoire. By 1962, his paintings were defined with color. The drawing from Luxembourg Gardens must be a very happy sight for him. The only drawings he actually used colors than taking notes of the colors are from Paris.

On $3^{\text {rd }}$ July 1967 drew Figure 16. There are rows of buses parked. In the foreground, there is a wooden bench. On the bench, Ziraat is written, indicating Ziraat Bank. There are color names on the windows of the buses and in the Latin alphabet yağliboya is written. Wheels and headlights of the buses are drawn as representative symbols rather in a quick and fun manner. Doodling is taking over hachures between the objects of the composition defining the surfaces, and creating rhythm.

These effects could be observed in Figure 17 and Figure 18 too. Figure 17 was drawn from Güven Park towards Emek commercial building. This structure is the first skyscraper of Turkey. It was built in 1959, and the scale and the image of the building became important for Ankara (Bayraktar, 2013, pp. 28, 29).
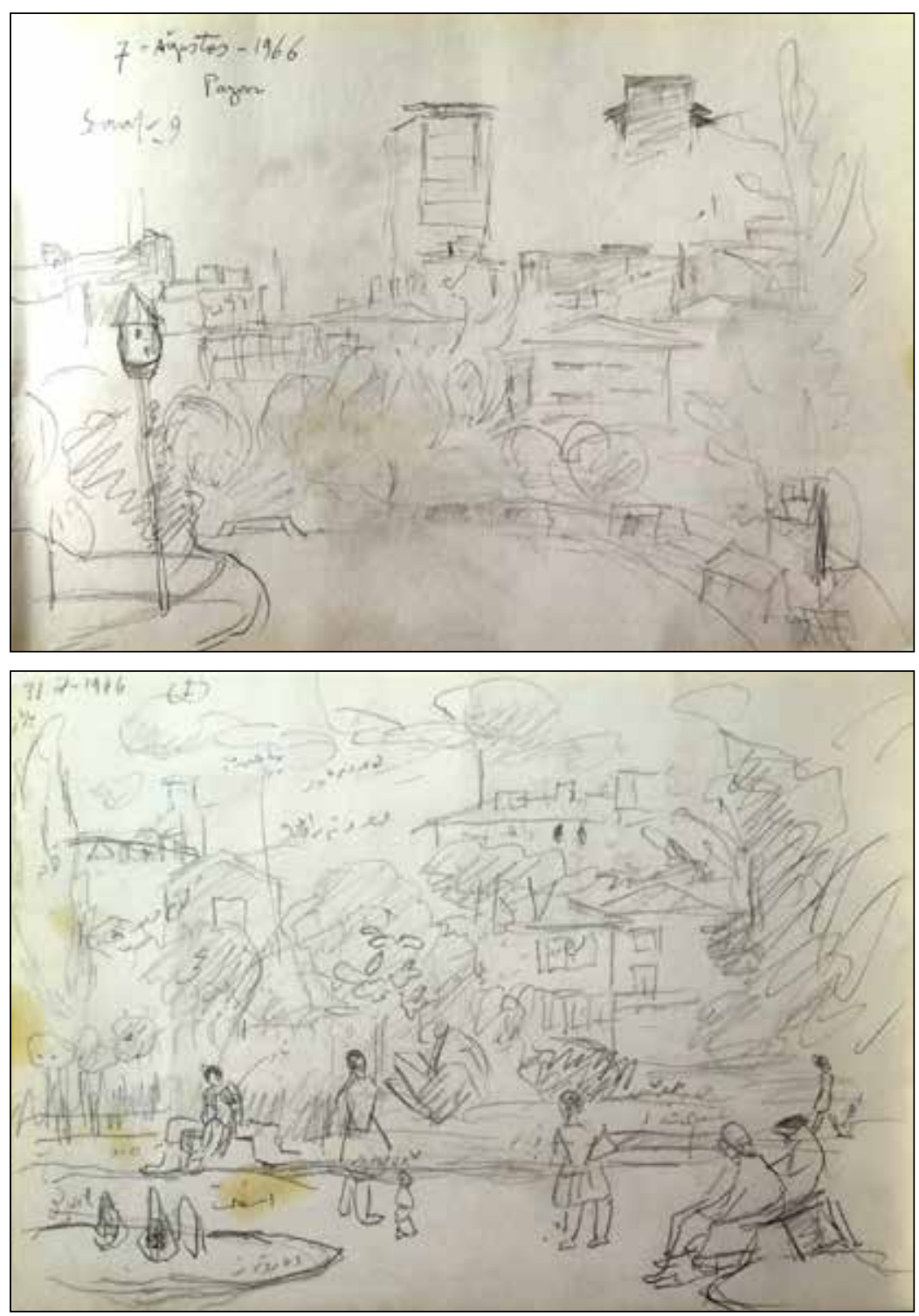

Figure 17. Eşref Üren,

$7^{\text {th }}$ August 1966, 15.5x23.7 $\mathrm{cm}$, pencil on paper. Source: İmren Erşen Collection, Ankara.
Figure 18. Eşref Üren, $31^{\text {st }}$ July $1966,16.5 \times 24 \mathrm{~cm}$, pencil on paper.

Source: İmren Erşen Collection, Ankara. 
It is very hard to tell the exact point of Figure 18 in the city, but its pool and fountains remind of Güven Park, which is adjacent to the Boulevard. Güven Park was built according to the 1932 Construction Plan of German town planner Herman Jansen (1869-1945) around 1935 (Burat, 2011, p. 113). This park was designed in a way to provide the passage through the ministry buildings in the area to the residences (Bayraktar, 2016, pp.72-73). In the late 1960s, Güven Park's and Kizılay Square's characteristic changed into the main center of the city (Bayratkar, 2013, p. 28). Although Kurtuluş Park is the main subject in Üren's paintings, these drawings signify that he also liked Güven Park and had intentions of painting it.

Only drawings Üren mentioned in his diaries is the Preparation for an Esquisse. Üren drew the building of Toprak Mahsülleri Ofisi (Agricultural Products Bureau) which was in Sihhiye district (Figure 19 and 20). On the $20^{\text {th }}$ January 1967, Üren wrote in his diary that there had been an offer to several painters to attend a competition (or some kind of tendering procedure which is not clear in his notes) for a panel in Toprak Mahsülleri Ofisi. On the $23^{\text {rd }}$ he met with Turan Erol (1927), another Turkish painter settled in Ankara, in Ankara Hotel to discuss the painting and see what he prepared. He wrote on $24^{\text {th }}$ and $25^{\text {th }}$ that he was anxious about this painting, so he prepared two drawings from two views. On the $26^{\text {th }}$ he drew Figures 19 and 20. And on $28^{\text {th }}$ he started to paint the esquisses. On $30^{\text {th }}$ he wrote "I have been thinking since the day I got the offer. Drawings are on my mind. I am thinking about them, especially the second one. Inspiration is thinking. I know how I am going to paint $i t^{\prime \prime}$. Unfortunately, on $17^{\text {th }}$ March 1967, he learned that Turan Erol won the competition (Üren, 1967, pp.1-2).

Figure 21 is the drawings of Hacettepe Hospitals buildings from Kurtuluş Park. Üren painted these scene at least five times. ${ }^{21}$ In his diaries, he wrote frequently that he went to the park that day.
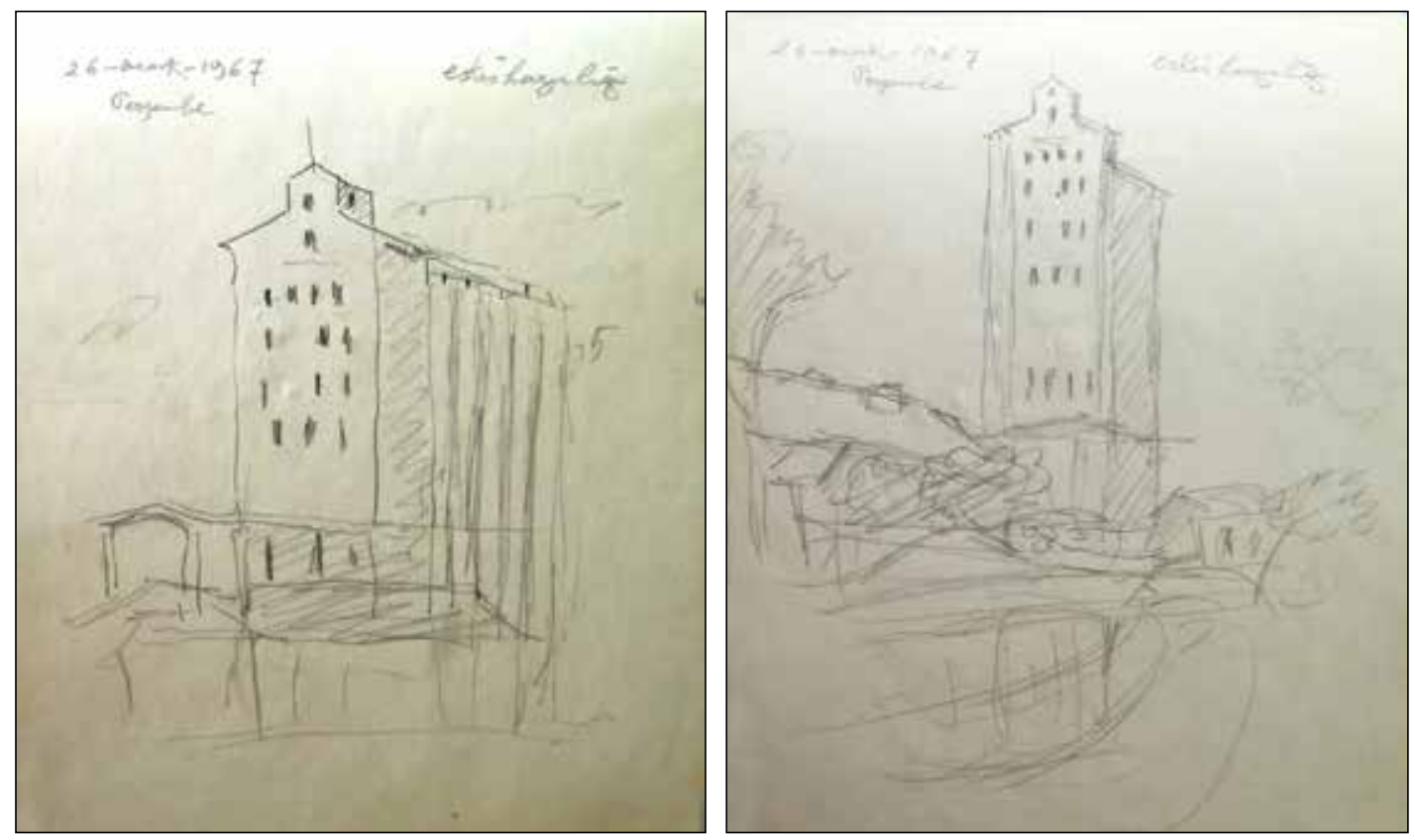

Figure 19 and 20. Eşref Üren, Preparation for an esquisse, $26^{\text {th }}$ January 1967 Thursday, $23.5 \times 16.5 \mathrm{~cm}$, pencil on paper. Source: İmren Erşen Collection, Ankara.

21 These paintings are published in the books as follows: Artam Antik AŞ 201. Müzayede Sergisi, Klasik ve Çağdaş Tablolar, Lot 71, İstanbul, p 61; Türkkaya Ataöv (1986). Eşref İsmail Üren. Ankara: Türkiye İş Bankası Yayınları, s. 41; Ares Antika ve Sanat Eserleri Müzayede Sergisi, 4 Nisan 2010, Lot 3, İstanbul; Beyaz Art Geri Benerdatte Koleksiyonu ve Seçkin Koleksiyonlardan Klasik Sanat Müzayede Sergisi, Lot 191, İstanbul; Artı Mezat Modern ve Çağdaş Türk Sanatı Müzayede Sergisi, 6 Nisan 2013, Lot 91, İstanbul; Artı Mezat Pax in Terris, 20 Nisan 2003 Müzayede Sergisi, Lot 22, İstanbul; Ankara Türkiye İş Bankası Sanat Galerisi-İstanbul Milli Reasürans Galerisi, 01-24 Nisan 1997, Eşref İsmail Üren Sergisi. 
Figure 22 is another drawing made from the corner of Güven Park that consists of Emek commercial building and many apartment buildings. This is the main commercial, cultural and social scene of the city in the late 1960s and early 1970s (Bayraktar, 2016, pp. 26-29).

\section{A New Route in Ankara}

In 1969 a tragedy occurred in Üren's life that eventually changed his route. His wife, the lifelong friend, and lover, Melahat Üren, died suddenly. This was a complete shock to Eşref Üren. He stopped, caring for himself and painting for a while. After a while, he moved to another apartment near Kurtuluş Park, in Ataç Street (Erşen, 2013, p. 184). In the last eight years of his life, he had walked in the city in a route. But these were not strolls. He kept to a routine which İmren Erşen quotes as follows:

Towards 11 a.m. he would wear his coat, scarf and walk through the same road, at the same time, greeting everybody he knew, and buy his newspaper from the kiosk on the corner of Mediha Eldem and İçel
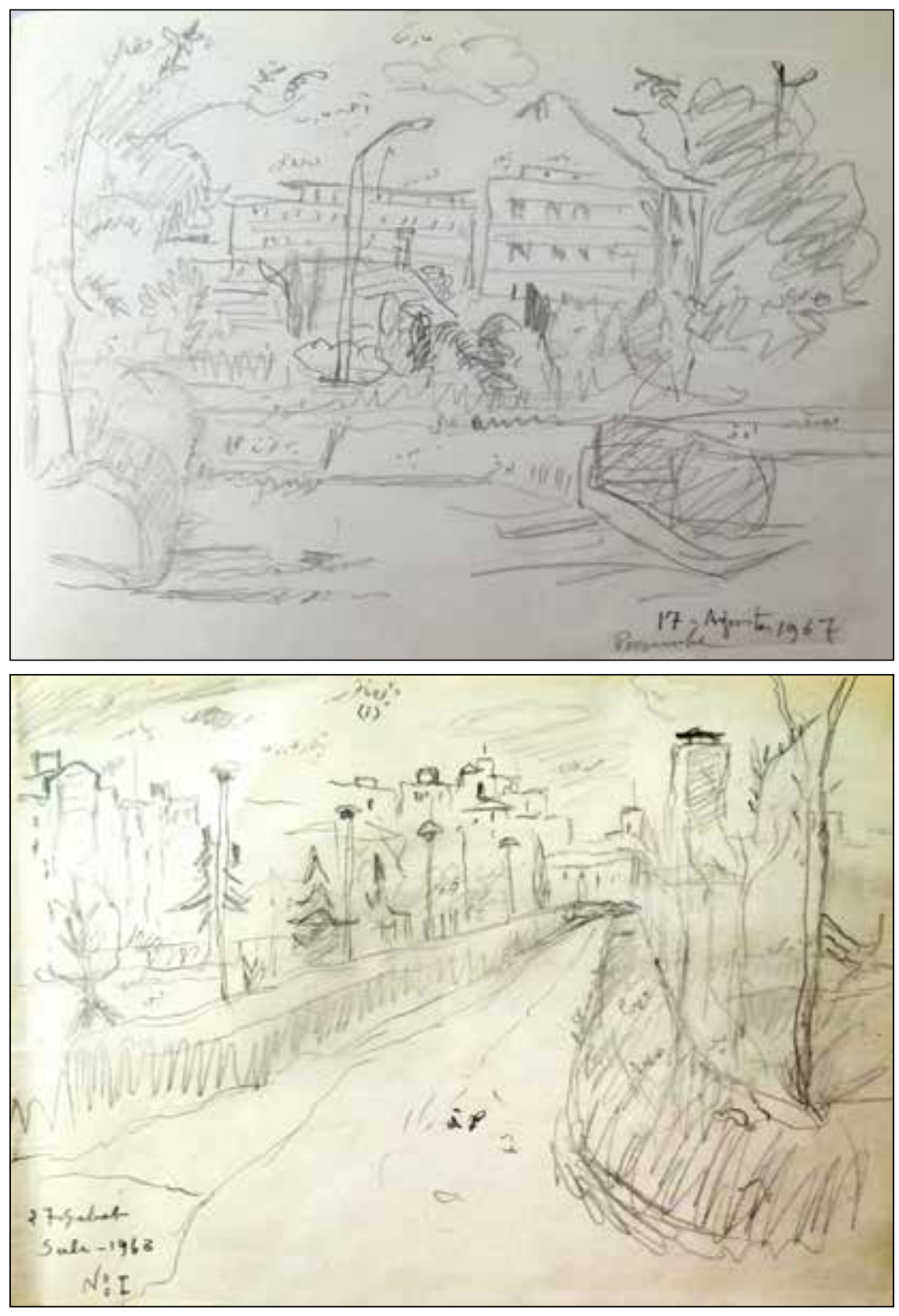

Figure 21. Eşref Üren, $17^{\text {th }}$ August 1967, pencil on paper. Source: İmren Erşen Collection, Ankara.

Figure 22. Eşref Üren, $27^{\text {th }}$ February 1968 Tuesday, $16.5 \times 23.5 \mathrm{~cm}$, pencil on paper. Source: İmren Erşen Collection, Ankara. 


\section{F. Akder, Ankara Drawings of Eşref Üren and Andre Lhôte's Influence
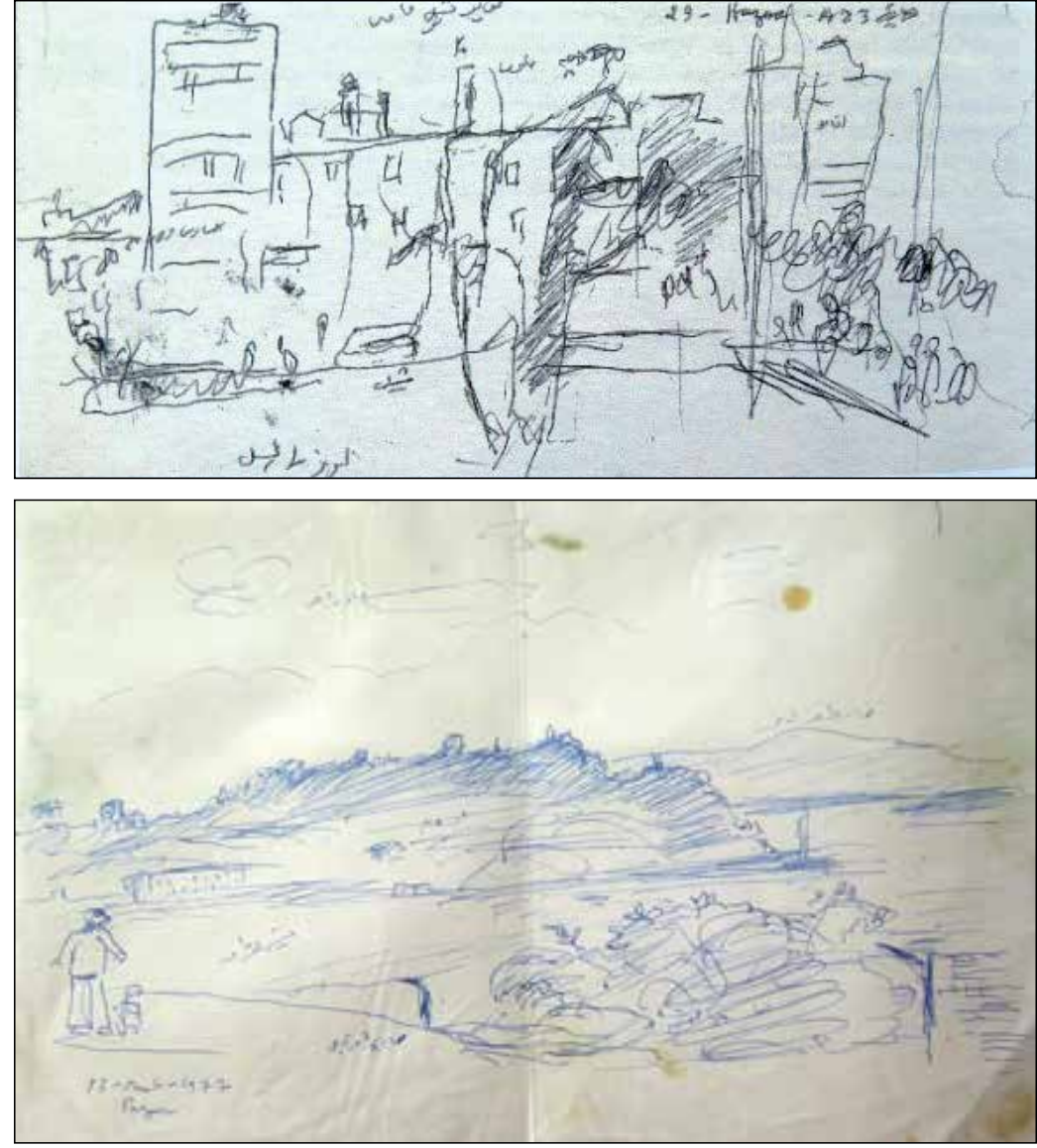

Figure 23. Eşref Üren, $29^{\text {th }}$ June $1983,10 \times 20 \mathrm{~cm}$, pen on paper.

Source: İmren Erşen Collection, Ankara.

Figure 24. Eşref Üren, Gölbaş1, 13 $3^{\text {th }}$ March 1977 Sunday, pen on paper. Source: İmren Erşen Collection, Ankara.

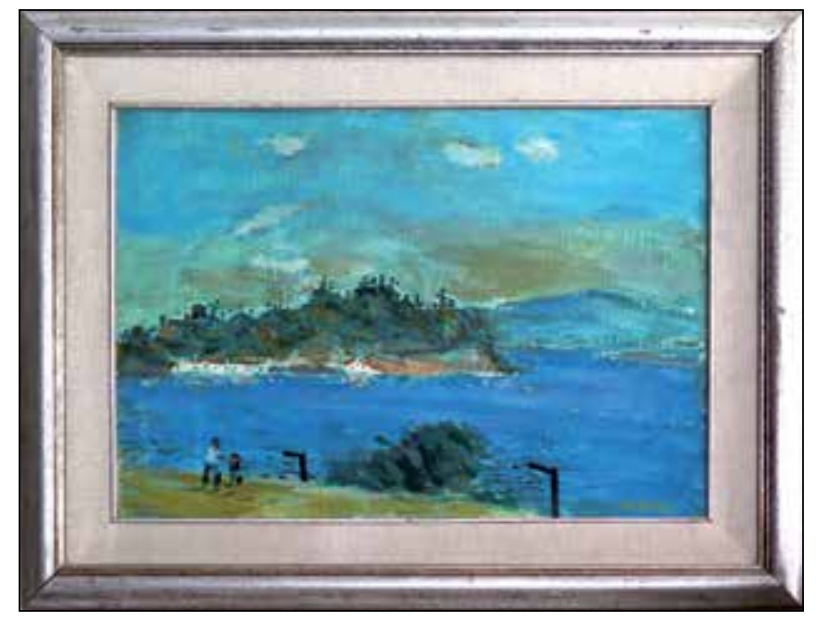

Figure 25. Eşref Üren, Gölbaşı, 1977, 35x50 cm, oil painting on cardboard.

Source: İmren Erşen Collection, Ankara.
Streets. Noon to half-past noon he would arrive at the Ticaretliler Sarayı on Mithatpaşa Road where he had his lunch. Every day towards half-past two p.m. he would go to the States Fine Arts Gallery. From there he would attend an exhibition opening. But most likely he would go to the Art Lovers Society. In the last eight years (1976-1984) except for the holidays, almost every day, I had been in this uniform, calm life. In the end, we would walk to Ataç Street from Tuna Street, where the Art Lover Society's hall was (Erşen ve Erinç, 1989, pp. 43, 44).

However, Üren kept drawing and painting to the end of his life. The emphasis was on this new route this time. Atatürk Bulvarı on Kizılay Square and the adjacent apartment buildings were a subject he worked frequently (Figure 23).

Üren's drawings were preliminary notes taken, and some of them eventually were turned into paintings. Figure 24 and 25 are examples of drawings and paintings matching. 


\section{Conclusion}

Had Eşref Üren's drawings been in the Museum collection, we would have to make a new category in the 1960s and 1970s. This category would be cityscape drawings indicating modern life within the drawing theories of André Lhôte that dominate the museum inventory between the 1930s to 1950 s.

The history of Turkish drawings starts in the early $19^{\text {th }}$ century, as mentioned before. Although it has three main sources, the dominant one, in the beginning, is the encounters of the students who were sent aboard to improve their education with European drawings. These students became teachers and headmasters as they returned and established two other sources: The Fine Arts Academy and military school drawing classes. The mentioned thesis tried to define the progress of Turkish drawings through these sources with the limitation of the Museum inventory. However, drawings such as Eşref Üren's Ankara drawings reveal a lot of information about the evolution of these theories into paintings in a different way than the museum inventory. Firstly Üren emphasized interruption of the lines, form, and surface arrangements hence the composition in his drawings. The majority of the drawings in the museum are about single figures or objects. What is more, there is a scarce number of landscape paintings, and the modern cityscape drawings are not-existent.

Üren's cityscape drawings mainly consist of the scenes from modern Ankara. These buildings and parks were designed according to the 1932 construction plan of Ankara by Herman Jansen. They point to the modern life of the city and Üren's life within the city. Figures of Üren are not detailed, and they do not signify any social status characteristic other than being in that area. As a result, we may conclude that one of Üren's characters were, in fact, these areas. This attitude becomes more significant in his texts printed in Ankara Art Journal about Kurtuluş Park and Atatürk Boulevard.

The contribution of Eşref Üren's Ankara drawings to the literature of art history is the prolonged influence of André Lhôte's theories. Literature of Turkish Art History often emphasizes Lhôte as the beginning of post-cubic and constructivist tendencies; however, it is not mentioned how this influence was carried into the post-war era. I claim drawings analyzed in this paper are connected to an encounter with European art between two wars and emphasizes the strength of the interactions.
These drawings also prove that Üren's paintings and compositions are the products of careful consideration of plastic values and modern art theories.

\section{References}

Akder, F. (2015). T.C. Mimar Sinan Güzel Sanatlar Üniversitesi Istanbul Devlet Resim Heykel Müzesi desen koleksiyonu. Unpublished doctoral dissertation, Mimar Sinan Güzel Sanatlar University Institute of Social Sciences, İstanbul.

Alpagut, L. (2017). Ankara'daki spor mekânları üzerinden bir gençlik tahayyülü. The Journal of International Social Research, 10(53), 921-932.

Anonymous. (1932). C.H.F. Halkevleri talimatnamesi. Ankara: Hâkimiyeti Milliye.

Anonymous. (1935). Halkevleri 1932-1935. Ankara: Hâkimiyeti Milliye.

Anonymous. (1937). Ankara Halkevi bir yıl içinde 300.000 yurttaşı çatısı altında topladı 1935-1936. Ankara: Ulus.

Anonymous. (1942). Halkevleri halkodaları 1932-1942. Ankara: Hâkimiyeti Milliye.

Anonymous. (1953). Milli Eğitim Vekilliği on dördüncü devlet resim ve heykel sergisi. Ankara: Milli Eğitim Bakanlı̆̆ı.

Aras, F. (2010). İhsan Cemal Karaburçak: yaşamı, eserleri, sanati. Unpublished Postgraduate Thesis, Mimar Sinan Güzel Sanatlar University Institute of Social Sciences, İstanbul.

Artun, D. (2007). Paris'ten modernlik tercümeleri: Académie Julian'da imparatorluk ve cumhuriyet öğrencileri. İstanbul: İletişim.

Bayraktar, N. (2013). Tarihe eş zamanlı tanıklık: Ulus ve Kızılay meydanlarının değişim süreci. Journal of Ankara Studies, 1(1). 20-35.

Bayraktar, N. (2016). Başkent Ankara'da cumhuriyet sonrası yaşanan büyük değişim: modern yaşam kurgusu ve modern mekânlar. Journal of Ankara Studies, 4(1), 67-80.

Berk, N. (1943). Sanat konuşmaları: denemeler. İstanbul: A.B.

Berk, N. (1964). Çallı İbrahim’in mezarı önünde, Varlık, 613, 7-7.

Bingöl, C. (1943). Unpublished letter to Eşref Üren, $14^{\text {th }}$ January 1943, İmren Erşen Collection, Ankara.

Boime, A. (1986). The academy and French painting in the nineteenth century. New Haven and London: Yale University.

Burat, S. (2011). Yeşilyollarda hareketle istirahat: Jansen planlarında başkentin kentsel yeşil alan tasarımları ve bunların uygulanma ve değiștirilme süreci (1932-1960). İdeal Kent, 4, 100-127. 
Cezar, M. (1995). Sanatta Batı'ya açılış ve Osman Hamdi. İstanbul: Erol Kerim Aksoy Kültür, Eğitim, Spor ve Sağllk Vakfi.

Cock, H. (1558). Cephalus en Procris landschappen met bijbelse en mythologische scenes. Etching on paper. $21.8 \times 30.5 \mathrm{~cm}$, RP-P-1886-A-10352, Rijksmuseum.

Çolak, İ. A. (2011). Kuruluşundan 1940’lara kadar geçen sürede askeri okulların Türk resim sanatına katkıları. Unpublished postgraduate thesis, Mimar Sinan Güzel Sanatlar University Institute of Social Sciences, İstanbul.

Erhan, K. (1980). Hoca Ali Rıza. İstanbul: Türkiye İş Bankası Kültür Yayınları.

Erol, T. (2000). Bozkırda yaz kış çiçek açan bir ağaç. In T. Erol, M. Özben, K. Özsezgin (Compiled by), Eşref Üren (pp. 4-7). Ankara: TCMB.

Erşen İ. (2014). Eşref Üren retrospektif. İstanbul: Türkiye İş Bankası Kültür Yayınları.

Erşen, İ. and Erinç, S.M. (1989). E. Üren. Ankara: Meteksan.

Genim, G. E. (2007). Nurullah Berk'in sanat yazıları. Unpublished Doctoral Dissertation, Marmara University Institute of Turkic Studies, İstanbul.

Güler, A. (2014). İbrahim Çallı. Unpublished Doctoral Dissertation, Mimar Sinan Güzel Sanatlar University Institute of Social Sciences, İstanbul.

Hoca Ali Rıza. (1967). Üstad-ı Alişanım Ressam Rıza Beyefendi Hazretlerinin samimi lisanından söylenen tercüme-i hali suretidir. In A.S. Ünver (Ed.). Kahvehanelerimiz ve eşyası (pp. 5-7). Ankara: Ankara Sanat.

Eyüboğlu, H. (Yay. Haz.) (2015). Bedri Rahmi Eyüboğlu ve çağdaşlarından mektuplar: biz mektup yazardık. İstanbul: Türkiye İş Bankası Kültür Yayınları.

Kaptan, A. (1970). Son sergisi ve kişiliğiyle Eşref Üren. Ankara Sanat, 5(49), 6-7.

Karpat, K. H. (1974). The impact of the people's houses on the development of communication in Turkey- 1931-1951. Die Welt des Islams, 15(1/4), 69-84.
Kizıltoprak, S. (2012). Ressam Hoca Ali Rıza ve Binbaşı Hasan Riza'nın resim dersi raporu. Ismek El Sanatları Dergisi, 12, 118-123.

Lhôte, A. (1950). Treatise on landscape painting. London: A. Zwemmer.

Mahir, B. (1988). Topkapı Sarayı Müzesi galerisindeki eserleriyle Joseph Schranz. Topkapı Palace Museum Annual, 3, 105125.

Müridoğlu, Z. (1992). Zühtü Müridoğlu kitabı. İstanbul: Yapı Kredi Yayınları.

Özsezgin, K. (1996). Mimar Sinan Üniversitesi İstanbul Resim Heykel Müzesi koleksiyonu. İstanbul: Yapı Kredi Yayınları.

Özyiğit, H. (2005). 1920-1928 yılları arasında süreli yayınlarda kültür ve sanat yorumlart: resim. Unpublished Postgraduate Thesis. Pamukkale University Institute of Social Sciences, Denizli.

Toksoy, N. (2007). Halkevleri: bir kültürel kalkınma modeli olarak. Ankara: Orion.

Tollu, C. S. (1935). Zafer Bayramı ve resim sergisi, Ülkü Journal, 32(6), 123-125.

Ural, M. (1997). Eşref Üren: firçam hala kurumadı. İstanbul: Milli Reasürans Art Gallery.

Üren, E. (1970). Enstantaneler. Ankara Sanat, 5(56), 6-7.

Üren, E. (1971a). Enstantaneler. Ankara Sanat, 6(65), 6-7.

Üren, E. (1971b). Enstantaneler. Ankara Sanat, 6(66), 6-7.

Üstünipek, Ş. (2009). 1936-1950 yılları arasında Güzel Sanatlar Akademisi: Léopold Lévy ve atölyesi. Unpublished Doctoral Dissertation, Mimar Sinan Güzel Sanatlar University Institute of Social Sciences, İstanbul.

Yasa Yaman, Z. (2002). D Grubu 1933-1951. In N. Elvan (Prep. by), D Grubu 1933-1951 (pp. 7-40). İstanbul: Yapı Kredi Yayınlar1. 
